\title{
Mono- and Bivalent Ligands Bearing Mannose 6-Phosphate (M6P) Surrogates: Targeting the M6P/Insulin-like Growth Factor II Receptor.
}

\author{
David B. Berkowitz, ${ }^{*}$ Gourhari Maiti, Bradley D. \\ Charette, Christine D. Dreis and Richard G. \\ MacDonald* \\ Department of Chemistry, University of Nebraska, Lincoln, NE \\ 68588-0304, and Department of Biochemistry \& Molecular Biology, \\ University of Nebraska Medical Center, Omaha, NE 68198-5870 \\ dbb@unlserve.unl.edu \\ rgmacdon@unmc.edu
}

SUPPORTING INFORMATION

\section{Organic Synthesis}

General. Reactions were conducted under argon atmosphere using oven-dried glassware. Methylene chloride and diisopropylamine were distilled from $\mathrm{CaH}_{2}$. THF and $\mathrm{Et}_{2} \mathrm{O}$ were distilled from sodium benzophenone ketyl. HMPA was distilled from calcum hydride under reduced pressure. Lithium bis(trimethyl)silylamide in hexane was purchased from Aldrich. Other reagents were obtained from commercial sources and used without further purification. Flash chromatography was performed using Merck silica gel 60 (230-400 mesh). ${ }^{1} \mathrm{H}$ NMR spectra were recorded on a Bruker-DRXAvance-500 MHz and $400 \mathrm{MHz}$ instrument with chemical shifts reported relative to residual $\mathrm{CHCl}_{3}(7.25 \mathrm{ppm})$. Proton-decoupled ${ }^{13} \mathrm{C}$ NMR spectra were acquired on a Bruker-DRX-Avance-500 and $400 \mathrm{MHz}$ instrument with chemical shifts reported relative to $\mathrm{CDCl}_{3}(77.0 \mathrm{ppm}) .{ }^{19} \mathrm{~F}$ and ${ }^{31} \mathrm{P} \mathrm{NMR}$ spectra were obtained on the $400 \mathrm{MHz}$ instrument. Mass spectra were acquired at the Nebraska Center for Mass Spectrometry (University of Nebraska-Lincoln). Optical rotations @589 nm were measured in an Autopol polarimeter. 


\section{Synthetic Procedures}

Dibenzyl diazomalonate (5). ${ }^{1}$ To a stirred solution of (4-acetamido)benzenesulfonyl azide $(5.07 \mathrm{~g}, 21.1 \mathrm{mmol})$ in acetonitrile $(20 \mathrm{~mL})$ and $\mathrm{NEt}_{3}(6.8 \mathrm{~mL}, 49.24 \mathrm{mmol})$ at 0 ${ }^{\circ} \mathrm{C}$ was slowly added a solution of dibenzylmalonate $(4.0 \mathrm{~g}, 14.06 \mathrm{mmol})$ in acetonitrile $(5 \mathrm{~mL})$. The reaction mixture was kept at $0{ }^{\circ} \mathrm{C}$ for $20 \mathrm{~min}$, then stirred at room temperature overnight. The thick white precipitate that formed was removed by filtration and the resulting filter cake washed with $\mathrm{Et}_{2} \mathrm{O}$. Evaporation of the volatiles gave the crude residue, which was purified by flash chromatography (20\% EtOAc-hexane) to give $\left.5^{1}(3.75 \mathrm{~g}, 86 \%):{ }^{1} \mathrm{H} \mathrm{NMR}\left(400 \mathrm{MHz}, \mathrm{CDCl}_{3}\right) \delta 5.27(\mathrm{~s}, 4 \mathrm{H}), 7.32-7.37 \mathrm{~m}, 10 \mathrm{H}\right)$ Methyl 6-(dibenzyl)2'- $O$-malonyl-2,3,4-tri- $O$-benzyl- $\alpha$-D-mannopyranoside (6). To a stirred solution of methyl 2,3,4 tri- $O$-benzyl mannopyranoside $2(4,464 \mathrm{mg}, 1.0 \mathrm{mmol})$ and rhodium acetate dimer ( $44 \mathrm{mg}, 0.1 \mathrm{mmol})$ in benzene $(15 \mathrm{~mL})$, under reflux, was added, dropwise, a solution of dibenzyl diazomalonate $5(310 \mathrm{mg}, 1.0 \mathrm{mmol})$ in benzene $(3 \mathrm{~mL})$. After complete addition, the reaction mixture was refluxed for $16 \mathrm{~h}$. Volatiles were removed under reduced pressure and the crude residue purified by flash chromatography (15\% EtOAc-hexane) to give $6(500 \mathrm{mg}, 67 \%)$ : ${ }^{1} \mathrm{H}$ NMR (500 MHz, $\left.\mathrm{CDCl}_{3}\right) \delta 3.20(\mathrm{~s}, 3 \mathrm{H}), 3.74-3.76(\mathrm{~m}, 2 \mathrm{H}), 3.85$ (dd, $\left.J=3,9 \mathrm{~Hz}, 1 \mathrm{H}\right) 3.88-3.91(\mathrm{~m}, 2 \mathrm{H})$, $3.96(\mathrm{dd}, J=1.6,12 \mathrm{~Hz}, 1 \mathrm{H}), 4.57(\mathrm{~d}, J=11 \mathrm{~Hz}, 1 \mathrm{H}), 4.59$ (s, 2H), $4.65(\mathrm{~d}, J=1.6 \mathrm{~Hz}$, $1 \mathrm{H}), 4.66(\mathrm{~d}, J=12 \mathrm{~Hz}, 1 \mathrm{H}), 4.70(\mathrm{~d}, J=12 \mathrm{~Hz}, 1 \mathrm{H}), 4.84(\mathrm{~d}, J=11 \mathrm{~Hz}, 1 \mathrm{H}), 5.00$ (s, $1 \mathrm{H}), 5.08(\mathrm{~d}, J=12 \mathrm{~Hz}, 1 \mathrm{H}), 5.12(\mathrm{~d}, J=12 \mathrm{~Hz}, 1 \mathrm{H}), 5.17(\mathrm{~d}, J=1.6 \mathrm{~Hz}, 1 \mathrm{H}), 7.24-7.35$ (m, $25 \mathrm{H}) ;{ }^{13} \mathrm{C} \mathrm{NMR}\left(125 \mathrm{MHz}, \mathrm{CDCl}_{3}\right) \delta 54.7,67.2,67.3,70.0,72.1,72.2,72.7,74.5$, 74.6, 74.9, 79.4, 80.0, 98.8, 127.4 (2C), 127.5, 127.7, 127.8, 128.1, 128.2 (3C), 128.3 (2C), 128.4, 128.5, 134.9, 135.0, 138.2, 138.4, 138.5, 166.3, 166.4; $[\alpha]^{23}{ }_{\mathrm{D}}+28.5$ $\left(\mathrm{CHCl}_{3}, c\right.$ 1.17); HRMS (FAB, 3-NOBA, LiI) calcd for $\mathrm{C}_{45} \mathrm{H}_{46} \mathrm{O}_{10} \mathrm{Li}\left(\mathrm{M}+\mathrm{Li}^{+}\right)$ 753.3251, obsd 753.3268.

Methyl 6-O-(2'-malonyl)- $\alpha$-D-mannopyranoside, bis(ammonium) salt (7). A solution of $6(160 \mathrm{mg}, 0.21 \mathrm{mmol})$ in 2:1 isopropyl alcohol/ethyl acetate $(6$ and $3 \mathrm{~mL}$ respectively) was stirred in the presence of $20 \% \mathrm{Pd}(\mathrm{OH})_{2} / \mathrm{C}(30 \mathrm{mg})$, under balloon pressure of hydrogen, overnight, at room temperature. Filtration (Celite), addition of aqueous $\mathrm{NH}_{4} \mathrm{HCO}_{3}(50 \mathrm{mM}, 5 \mathrm{~mL}$ ), evaporation and drying (high vacuum) gave 7 (50 mg, 73\%): ${ }^{1} \mathrm{H}$ NMR (400 MHz, MeOD) $\delta 3.35$ (s, 3H), 3.50-3.52 (m, 1H), 3.65-3.70 (m, $2 \mathrm{H}), 3.76(\mathrm{dd}, J=2.3,10 \mathrm{~Hz}, 1 \mathrm{H}), 3.80-3.82(\mathrm{~m}, 1 \mathrm{H}), 4.01(\mathrm{t}, J=10 \mathrm{~Hz}, 1 \mathrm{H}), 4.24(\mathrm{~s}$, 
1H), $4.67(\mathrm{~d}, J=1.2 \mathrm{~Hz}, 1 \mathrm{H}) ;{ }^{13} \mathrm{C} \mathrm{NMR}(100 \mathrm{MHz}, \mathrm{MeOD}) \delta 55.6,67.8,68.6,72.3$ (2C), 73.3, 86.1, 103.1, 176.1, 176.2; $[\alpha]{ }^{23}{ }_{\mathrm{D}}+54.6\left[\mathrm{MeOH}: \mathrm{H}_{2} \mathrm{O}(1: 1), c\right.$ 0.52]; HRMS (FAB, Gly.) calcd for $\mathrm{C}_{10} \mathrm{H}_{17} \mathrm{O}_{10}\left(\mathrm{M}+\mathrm{H}^{+}\right)$297.0822, obsd 297.0833.

\section{Methyl 2,3,4 tri- $O$-benzyl-6- $O$-trifluoromethanesulfonyl- $\alpha$-D-mannopyranoside (8).}

To a solution of methyl 2,3,4 tri- $O$-benzyl mannopyranoside $(620 \mathrm{mg}, 1.33 \mathrm{mmol})^{2}$ and 2,6-di-tert-butyl-4-methylpyridine ( $685 \mathrm{mg}, 3.4 \mathrm{mmol})$ in $\mathrm{CH}_{2} \mathrm{Cl}_{2}(6 \mathrm{~mL})$, was slowly added trifluoromethanesulfonic anhydride $(335 \mu \mathrm{L}, 2.0 \mathrm{mmol})$ at $-40{ }^{\circ} \mathrm{C}$ and stirring continued for $1.5 \mathrm{~h}$ at that temperature. The reaction mixture was diluted with $\mathrm{Et}_{2} \mathrm{O}$, and was washed sequentially with saturated aqueous $\mathrm{NH}_{4} \mathrm{Cl}$ and saturated aqueous $\mathrm{NaHCO}_{3}$. The organic layer was dried $\left(\mathrm{MgSO}_{4}\right)$, filtered and evaporated. Purification by flash chromatography over $\mathrm{SiO}_{2}\left(20 \% \mathrm{Et}_{2} \mathrm{O}\right.$-hexane) afforded $\mathbf{8}(673 \mathrm{mg}, 85 \%)$ as a colorless oil: ${ }^{1} \mathrm{H}$ NMR ( $500 \mathrm{MHz}, \mathrm{CDCl}_{3}$ ) $\delta 3.32(\mathrm{~s}, 3 \mathrm{H}), 3.80(\mathrm{dd}, J=2,3 \mathrm{~Hz}, 1 \mathrm{H}), 3.84-3.88$ (m, 2H), 3.90-3.93 (m, 1H), 4.55-4.65 (m, 2H), $4.59(\mathrm{~d}, J=11 \mathrm{~Hz}, 1 \mathrm{H}), 4.60(\mathrm{~d}, J=12$ $\mathrm{Hz}, 1 \mathrm{H}), 4.62(\mathrm{~d}, J=11 \mathrm{~Hz}, 1 \mathrm{H}), 4.63(\mathrm{~d}, J=12 \mathrm{~Hz}, 1 \mathrm{H}), 4.69(\mathrm{~d}, J=12 \mathrm{~Hz}, 1 \mathrm{H}), 4.73$ (d, $J=2 \mathrm{~Hz}, 1 \mathrm{H}), 4.74$ (d, $J=12 \mathrm{~Hz} .1 \mathrm{H}), 4.98$ (d, $J=11 \mathrm{~Hz}, 1 \mathrm{H}), 2.28-7.40$ (m, 15H).

\section{Methyl 6-deoxy-6-(dibenzyl)2'-malonyl-2,3,4-tri- $O$-benzyl- $\alpha$-D-mannopyranoside}

(9). To a stirred solution of dibenzyl malonate $(715 \mathrm{mg}, 2.52 \mathrm{mmol})$ in THF $(10 \mathrm{~mL})$ at $-78{ }^{\circ} \mathrm{C}$ was added LiHMDS (2.52 $\mathrm{mL}, 1 \mathrm{M}$ in hexane, $\left.2.52 \mathrm{mmol}\right)$, dropwise, and with stirring. After $30 \mathrm{~min}$, a solution of triflate $8(500 \mathrm{mg}, 0.84 \mathrm{mmol})$ in THF $(5 \mathrm{~mL})$ was added via cannula at $-78{ }^{\circ} \mathrm{C}$. The reaction mixture was allowed to slowly warm to room temperature. After $6 \mathrm{~h}$, the reaction was quenched by addition of $\mathrm{NH}_{4} \mathrm{Cl}$ (aq) and extracted with EtOAc. The organic layer was washed with brine, dried $\left(\mathrm{MgSO}_{4}\right)$, filtered and concentrated. Flash chromatography over $\mathrm{SiO}_{2}$ (20\% EtOAc-hexane) afforded 9 (324 mg, 54\%): ${ }^{1} \mathrm{H}$ NMR $\left(400 \mathrm{MHz}, \mathrm{CDCl}_{3}\right) \delta 2.15$ (ddd, $J=5,10,14, \mathrm{~Hz}$, $1 \mathrm{H}), 2.63(\mathrm{ddd}, J=2.5,10,12 \mathrm{~Hz}, 1 \mathrm{H}), 3.11(\mathrm{~s}, 3 \mathrm{H}), 3.53(\mathrm{dt}, J=2.4,10 \mathrm{~Hz}, 1 \mathrm{H}), 3.66$ (t, $J=9 \mathrm{~Hz}, 1 \mathrm{H}), 3.72(\mathrm{dd}, J=2,3 \mathrm{~Hz}, 1 \mathrm{H}), 3.78(\mathrm{~d}, J=10 \mathrm{~Hz}, 1 \mathrm{H}), 3.79(\mathrm{dd}, J=2,9$ $\mathrm{Hz}, 1 \mathrm{H}), 4.53(\mathrm{~d}, J=1.6 \mathrm{~Hz}, 1 \mathrm{H}), 4.58(\mathrm{~s}, 2 \mathrm{H}), 4.64(\mathrm{~d}, J=11 \mathrm{~Hz}, 1 \mathrm{H}), 4.67(\mathrm{~d}, J=12$ $\mathrm{Hz}, 1 \mathrm{H}), 4.72(\mathrm{~d}, J=12 \mathrm{~Hz}, 1 \mathrm{H}), 4.92(\mathrm{~d}, J=11 \mathrm{~Hz}, 1 \mathrm{H}), 5.12(\mathrm{~d}, J=4 \mathrm{~Hz}, 4 \mathrm{H}), 7.23-$ $7.35(\mathrm{~m}, 25 \mathrm{H}) ;{ }^{13} \mathrm{C}$ NMR $\left(125 \mathrm{MHz}, \mathrm{CDCl}_{3}\right) \delta 38.2,48.8,54.7,67.0(2 \mathrm{C}), 69.0,72.1$, 72.7, 74.5, 75.1, 78.6, 79.9, 98.9, 127.4, 127.5 (2C), 127.6, 127.8 (2C), 128.1, 128.2 (2C), 128.3, $128.4(2 \mathrm{C}), 135.3,135.4,138.2,138.4,168.8,169.1 ;[\alpha]^{23}{ }_{\mathrm{D}}+20.2\left(\mathrm{CHCl}_{3}\right.$, 
c 1.33); HRMS (FAB, 3-NOBA, LiI) calcd for $\mathrm{C}_{45} \mathrm{H}_{46} \mathrm{O}_{9} \mathrm{Li}\left(\mathrm{M}+\mathrm{Li}^{+}\right)$737.3302, obsd 737.3326.

Methyl 6-deoxy-6-(2'-malonyl)- $\alpha$-D-mannopyranoside, bis(ammonium) salt (10). A solution of $9(170 \mathrm{mg}, 0.23 \mathrm{mmol})$ in 2:1 isopropyl alcohol/ethyl acetate $(5$ and $2.5 \mathrm{~mL}$ respectively) was stirred under balloon pressure of hydrogen overnight at room temperature in the presence of $20 \% \mathrm{Pd}(\mathrm{OH})_{2} / \mathrm{C}(36 \mathrm{mg})$. Filtration (Celite) and neutralization with aqueous $\mathrm{NH}_{4} \mathrm{HCO}_{3}(50 \mathrm{mM}, 5 \mathrm{~mL})$ gave $10(60 \mathrm{mg}, 82 \%)$, following evaporation and drying on the high vacuum: ${ }^{1} \mathrm{H}$ NMR $\left(400 \mathrm{MHz}, \mathrm{D}_{2} \mathrm{O}\right) \delta 1.89$ (ddd, $J=$ 4.5, 10, $14 \mathrm{~Hz}, 1 \mathrm{H}), 2.38-2.44$ (m, $1 \mathrm{H}), 3.35$ (s, 3H), 3.38-3.48 (m, 3H), 3.67 (dd, $J=3$, $9 \mathrm{~Hz}, 1 \mathrm{H}), 3.87(\mathrm{dd}, J=1.4,3 \mathrm{~Hz}, 1 \mathrm{H}), 4.66(\mathrm{~s}, 1 \mathrm{H}) ;{ }^{13} \mathrm{C} \mathrm{NMR}\left(100 \mathrm{MHz}, \mathrm{D}_{2} \mathrm{O}\right) \delta 31.8$, 52.1, 54.8, 69.9, 70.1, 70.3, 70.8, 100.7, 177.3, 177.7; $[\alpha]^{23}{ }_{\mathrm{D}}+48.1\left[\mathrm{MeOH}: \mathrm{H}_{2} \mathrm{O}(1: 1)\right.$, c 0.69]; HRMS (FAB, Gly.) calcd for $\mathrm{C}_{10} \mathrm{H}_{17} \mathrm{O}_{9}\left(\mathrm{M}+\mathrm{H}^{+}\right)$281.0873, obsd 281.0867; HRMS (FAB, Gly, negative ion mode) calcd for $\mathrm{C}_{10} \mathrm{H}_{15} \mathrm{O}_{9}$, (M-H') 279.0716, obsd 279.0714 .

\section{Methyl 6-deoxy-6-(dibenzyl)phosphonomethyl-2,3,4-tri- $O$-benzyl- $\alpha$-D -} mannopyranoside (11). To a magnetically stirred solution of dibenzyl methylphosphonate $(694 \mathrm{mg}, 2.52 \mathrm{mmol})$ in THF $(10 \mathrm{~mL})$ at $-78^{\circ} \mathrm{C}$ was added slowly $n$ BuLi (1.86 $\mathrm{mL}$ of a $1.35 \mathrm{M}$ solution in hexane, $2.52 \mathrm{mmol}$ ), and the reaction mixture stirred for $30 \mathrm{~min}$ at that temperature. A solution of triflate $8(500 \mathrm{mg}, 0.83 \mathrm{mmol})$ in THF $(5 \mathrm{~mL})$ was added slowly. After stirring for $1 \mathrm{~h}$ at $-78{ }^{\circ} \mathrm{C}$, the reaction was quenched with saturated aqueous $\mathrm{NH}_{4} \mathrm{Cl}$. Following dilution with EtOAc $(100 \mathrm{~mL})$, the organic layer was washed sequentially with $\mathrm{NH}_{4} \mathrm{Cl}$, water and brine. Drying $\left(\mathrm{MgSO}_{4}\right)$, filtration and evaporation gave crude product, which was purified by $\mathrm{SiO}_{2}$ flash chromatography ( $50 \rightarrow 60 \%$ EtOAc-hexane) to afford $11(410 \mathrm{mg}, 68 \%)$ as a colorless oil: ${ }^{1} \mathrm{H}$ NMR (400 MHz, $\left.\mathrm{CDCl}_{3}\right) \delta 1.71-1.88(\mathrm{~m}, 2 \mathrm{H}), 2.06-2.25(\mathrm{~m}, 2 \mathrm{H}), 3.22(\mathrm{~s}, 3 \mathrm{H})$, 3.47 (dt, $J=2.5,9 \mathrm{~Hz}, 1 \mathrm{H}), 3.63(\mathrm{t}, J=9 \mathrm{~Hz}, 1 \mathrm{H}), 3.77(\mathrm{dd}, J=2,3 \mathrm{~Hz}, 1 \mathrm{H}), 3.82(\mathrm{dd}, J$ $=3,9 \mathrm{~Hz}, 1 \mathrm{H}), 4.58(\mathrm{~d}, J=11 \mathrm{~Hz}, 1 \mathrm{H}), 4.60(\mathrm{~s}, 2 \mathrm{H}), 4.64(\mathrm{~d}, J=1.6 \mathrm{~Hz}, 1 \mathrm{H}), 4.70(\mathrm{~d}, J$ $=12 \mathrm{~Hz}, 1 \mathrm{H}), 4.75(\mathrm{~d}, J=12 \mathrm{~Hz}, 1 \mathrm{H}), 4.91(\mathrm{~d}, J=12 \mathrm{~Hz}, 1 \mathrm{H}), 4.95(\mathrm{dd}, J=0.7,12 \mathrm{~Hz}$, 1H), 4.97 (dd, $J=1.3,12 \mathrm{~Hz}, 1 \mathrm{H}), 5.03(\mathrm{dd}, J=1.2,12 \mathrm{~Hz}, 1 \mathrm{H}), 5.04$ (dd, $J=1.3,12$ $\mathrm{Hz}, 1 \mathrm{H}), 7.24-7.38$ (m, 25H); ${ }^{13} \mathrm{C} \mathrm{NMR}\left(100 \mathrm{MHz}, \mathrm{CDCl}_{3}\right) \delta 22.1$ (d, $\left.J=143 \mathrm{~Hz}\right), 24.6$ (d, $J=4 \mathrm{~Hz}), 54.5,66.9$ (d, $J=1.7 \mathrm{~Hz}), 67.0(\mathrm{~d}, J=1.7 \mathrm{~Hz}), 71.1$ (d, $J=17 \mathrm{~Hz}), 72.0$, 72.7, 74.5, 75.2, 78.1, 80.1, 98.9, 127.5 (3C), 127.6, 127.8 (3C) 127.9, 128.2, 128.3, 
128.5, $136.4(\mathrm{~d}, J=6 \mathrm{~Hz}), 138.2,138.3,138.4 ;{ }^{31} \mathrm{P} \mathrm{NMR}\left(162 \mathrm{MHz}, \mathrm{CDCl}_{3}\right) \delta 33.19$; $[\alpha]^{23}{ }_{\mathrm{D}}+26.6\left(\mathrm{CHCl}_{3}, c\right.$ 1.3); HRMS (FAB, 3-NOBA, LiI) calcd for $\mathrm{C}_{43} \mathrm{H}_{47} \mathrm{O}_{8} \mathrm{PLi}$ $\left(\mathrm{M}+\mathrm{Li}^{+}\right) 729.3169$, obsd 729.3142 .

Methyl 6-deoxy-6-phosphonomethyl- $\alpha$-D-mannopyranoside, bis(ammonium) salt (12). A solution of $\mathbf{1 1}(185 \mathrm{mg}, 0.25 \mathrm{mmol})$ in $2: 1$ isopropyl alcohol/ethyl acetate (8 and $4 \mathrm{~mL}$, respectively) was stirred under balloon pressure of hydrogen at room temperature overnight in the presence of $20 \% \mathrm{Pd}(\mathrm{OH})_{2} / \mathrm{C}(36 \mathrm{mg})$. Catalyst was filtered off (Celite) and aqueous $\mathrm{NH}_{4} \mathrm{HCO}_{3}(50 \mathrm{mM}, 5 \mathrm{~mL})$ was added. Evaporation and drying on the high vacuum provided the desired phosphonate, as its ammonium salt $(60 \mathrm{mg}, 78 \%):{ }^{1} \mathrm{H}$ NMR (400 MHz, $\left.\mathrm{D}_{2} \mathrm{O}\right) \delta$ 1.56-1.79 (m, 2H), 1.82-1.92 (m, 1H), 1.99-2.11 (m, 1H), 3.36 (s, 3H), 3.48-3.54 (m, 2H), 3.68 (dd, $J=3,9 \mathrm{~Hz}, 1 \mathrm{H}), 3.89$ (app t, $J=1.6 \mathrm{~Hz}, 1 \mathrm{H}), 4.69$ (s, 1H); ${ }^{13} \mathrm{C}$ NMR (100 MHz, $\left.\mathrm{D}_{2} \mathrm{O}\right) \delta 23.7$ (d, $\left.J=135 \mathrm{~Hz}\right), 24.9$ (d, $\left.J=4 \mathrm{~Hz}\right), 54.6$, 69.8, 70.0, 70.4, $72.2(\mathrm{~d}, J=17 \mathrm{~Hz}), 100.7$; ${ }^{31} \mathrm{P}$ NMR $\left(162 \mathrm{MHz}, \mathrm{D}_{2} \mathrm{O}\right) \delta 25.39 ;[\alpha]^{23} \mathrm{D}$ + $58.5\left[\mathrm{MeOH}: \mathrm{H}_{2} \mathrm{O}(1: 1), c\right.$ 0.32]; HRMS (FAB, Gly.) calcd for $\mathrm{C}_{8} \mathrm{H}_{17} \mathrm{O}_{8} \mathrm{P}\left(\mathrm{M}+\mathrm{H}^{+}\right)$ 273.0739, obsd 273.0750.

Allyl 2,3,4-tri- $\boldsymbol{O}$-benzyl- $\alpha$-D-mannopyranoside (13). Methyl-2,3,4-tri-O-benzyl- $\alpha-D-$ mannopyranoside $(4,10.0 \mathrm{~g}, 21.5 \mathrm{mmol})$ was taken up in allyl alcohol $(70 \mathrm{~mL})$ and saturated with $\mathrm{HCl}$ at $0{ }^{\circ} \mathrm{C}$. The reaction mixture was heated at $60^{\circ} \mathrm{C}$ for $6 \mathrm{~h}$ and then kept at room temperature overnight. The clear solution obtained was neutralized with $\mathrm{NaHCO}_{3}$ and then filtered through Celite. Flash chromatography $(15 \rightarrow 20 \%$ EtOAchexane) afforded pure $13(5.33 \mathrm{~g}, 50 \%)$ as an oil: ${ }^{1} \mathrm{H}$ NMR $\left(500 \mathrm{MHz}, \mathrm{CDCl}_{3}\right) \delta 2.12(\mathrm{br}$ s, 1H), 3.68 (ddd, $J=3,5,9 \mathrm{~Hz}, 1 \mathrm{H}), 3.37-3.87$ (m, 3H), 3.90-3.94 (m, 1H), 3.96 (dd, $J$ $=3,9 \mathrm{~Hz}, 1 \mathrm{H}), 4.01(\mathrm{t}, J=9 \mathrm{~Hz}, 1 \mathrm{H}), 4.11-4.15(\mathrm{~m}, 1 \mathrm{H}), 4.66(\mathrm{~s}, 2 \mathrm{H}), 4.67(\mathrm{~d}, J=9 \mathrm{~Hz}$, $1 \mathrm{H}), 4.70(\mathrm{~d}, J=12 \mathrm{~Hz}, 1 \mathrm{H}), 4.80(\mathrm{~d}, J=12 \mathrm{~Hz}, 1 \mathrm{H}), 4.86(\mathrm{~d}, J=1.7 \mathrm{~Hz}, 1 \mathrm{H}), 4.95(\mathrm{~d}, J$ $=9 \mathrm{~Hz}, 1 \mathrm{H}), 5.15-5.24(\mathrm{~m}, 2 \mathrm{H}), 5.80-5.88(\mathrm{~m}, 1 \mathrm{H}), 7.25-7.38(\mathrm{~m}, 15 \mathrm{H}) ;{ }^{13} \mathrm{C} \mathrm{NMR}(100$ $\left.\mathrm{MHz}, \mathrm{CDCl}_{3}\right) \delta 62.3,67.8,72.2(2 \mathrm{C}), 72.9,74.8,74.9,75.2,80.2,97.4,117.3,127.5$ (2C), 127.6, 127.7, 127.8, 128.0, 128.3, 128.4, 133.6, 138.2, 138.3, 138.4; $[\alpha]^{23}{ }_{\mathrm{D}}+43.6$ $\left(\mathrm{CHCl}_{3}, c 1.0\right)$; HRMS (FAB, 3-NOBA, LiI) calcd for $\mathrm{C}_{30} \mathrm{H}_{34} \mathrm{O}_{6} \mathrm{Li}\left(\mathrm{M}+\mathrm{Li}^{+}\right)$497.2515, obsd 497.2507.

Allyl 2,3,4-tri- $O$-benzyl-6- $O$-trifluoromethanesulfonyl- $\alpha$-D mannopyranoside (14).

To a solution of 13 (400 mg, $0.82 \mathrm{mmol}$ ) and 2,6-di-tert-butyl-4-methylpyridine (500 $\mathrm{mg}, 2.44 \mathrm{mmol})$ in $\mathrm{CH}_{2} \mathrm{Cl}_{2}(5 \mathrm{~mL})$, was added trifluoromethanesulfonic anhydride (206 
$\mu \mathrm{L}, 1.23 \mathrm{mmol}$ ), slowly at $-40{ }^{\circ} \mathrm{C}$. After stirring for $2 \mathrm{~h}$ at that temperature, the reaction mixture was diluted with $\mathrm{Et}_{2} \mathrm{O}$, and partitioned with saturated, aqueous $\mathrm{NH}_{4} \mathrm{Cl}$, and then saturated, aqueous $\mathrm{NaHCO}_{3}$. Drying $\left(\mathrm{MgSO}_{4}\right)$, fitration and evaporation were followed by flash chromatography (15\% $\mathrm{Et}_{2} \mathrm{O}$-hexane) to give 14 (400 mg, 79\%): ${ }^{1} \mathrm{H}$ NMR (400

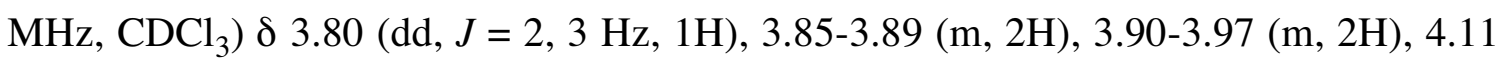
(ddt, $J=1.4,5,13 \mathrm{~Hz}, 1 \mathrm{H}), 4.54-4.65(\mathrm{~m}, 5 \mathrm{H}), 4.67$ (d, $J=12 \mathrm{~Hz}, 1 \mathrm{H}), 4.74$ (d, $J=12$ $\mathrm{Hz}, 1 \mathrm{H}), 4.87$ (d, $J=1.7 \mathrm{~Hz}, 1 \mathrm{H}), 4.97$ (d, $J=11 \mathrm{~Hz}, 1 \mathrm{H}), 5.16-5.24$ (m, 2H), 5.77-5.87 $(\mathrm{m}, 1 \mathrm{H}), 7.27-7.37(\mathrm{~m}, 15 \mathrm{H}) ;{ }^{13} \mathrm{C} \mathrm{NMR}\left(100 \mathrm{MHz}, \mathrm{CDCl}_{3}\right) \delta 68.1,69.9,72.1,72.2$, 73.5, 74.3, 75.2, 75.4, 80.0, 96.9, 117.7, 118.6 (q, $J=318$ Hz), 127.7, 127.8, 128.0, 128.1, 128.4 (2C), 128.5, 133.2, 137.7, 137.9, 138.0; ${ }^{19} \mathrm{~F} \mathrm{NMR}\left(376 \mathrm{MHz}, \mathrm{CDCl}_{3}\right) \delta$ 75.36 .

\section{Allyl 6-deoxy-6-(dibenzyl)-2'-malonyl-2,3,4-tri- $O$-benzyl- $\alpha$-D-mannopyranoside} (15). To a stirred solution of dibenzyl malonate $(680 \mathrm{mg}, 2.40 \mathrm{mmol})$ in THF $(10 \mathrm{~mL})$ at $-78{ }^{\circ} \mathrm{C}$ was added slowly LiHMDS (2.4 $\mathrm{mL}, 1 \mathrm{M}$ solution in hexane, $\left.2.4 \mathrm{mmol}\right)$. After $30 \mathrm{~min}$, a solution of triflate 14 (400 mg, $0.64 \mathrm{mmol})$ in THF (5 mL) was added, dropwise, via cannula, over $10 \mathrm{~min}$. The reaction mixture was allowed to warm to rt and stirred for $6 \mathrm{~h}$. The reaction mixture was partitioned between aqueous $\mathrm{NH}_{4} \mathrm{Cl}$ and $\mathrm{Et}_{2} \mathrm{O}$. The organic layer was further washed with brine, dried over $\mathrm{MgSO}_{4}$, filtered and concentrated. Flash chromatography (20\% EtOAc-hexane) afforded 15 (240 mg, 50\%): ${ }^{1} \mathrm{H}$ NMR $\left(500 \mathrm{MHz}, \mathrm{CDCl}_{3}\right) \delta 2.18$ (ddd, $\left.J=5,10,14 \mathrm{~Hz}, 1 \mathrm{H}\right), 2.65$ (ddd, $J=2.5,10$, $14 \mathrm{~Hz}, 1 \mathrm{H}), 3.61(\mathrm{td}, J=2.3,10 \mathrm{~Hz}, 1 \mathrm{H}), 3.69(\mathrm{t}, J=9 \mathrm{~Hz}, 1 \mathrm{H}), 3.74-3.80(\mathrm{~m}, 3 \mathrm{H}), 3.86$ $(\mathrm{dd}, J=3,9 \mathrm{~Hz}, 1 \mathrm{H}), 3.99-4.03(\mathrm{~m}, 1 \mathrm{H}), 4.62(\mathrm{~s}, 2 \mathrm{H}), 4.66(\mathrm{~d}, J=11 \mathrm{~Hz}, 1 \mathrm{H}), 4.68(\mathrm{~d}, J$ $=12 \mathrm{~Hz}, 1 \mathrm{H}), 4.71(\mathrm{~d}, J=1.6 \mathrm{~Hz}, 1 \mathrm{H}), 4.74(\mathrm{~d}, J=12 \mathrm{~Hz}, 1 \mathrm{H}), 4.94(\mathrm{~d}, J=11 \mathrm{~Hz}, 1 \mathrm{H})$, 5.09-5.18 (m, 6H), 5.68-5.76 (m, 1H), 7.18-7.36 (m, 25H); ${ }^{13} \mathrm{C}$ NMR $(125 \mathrm{MHz}$, $\left.\mathrm{CDCl}_{3}\right) \delta 31.1,48.9,67.0,67.5$, , 69.4, 72.2, 72.8, 74.6, 75.2, 78.6, 80.0, 96.8, 117.0, $127.5,127.6$ (2C), 127.8, 127.9, 128.0, 128.1, 128.2, 128.3 (2C), 128.4, 128.5, 133.6, 135.3, 135.4, 138.2, 138.3, 138.4. 168.7, 169.1; $[\alpha]^{23}{ }_{\mathrm{D}}+30.2\left(\mathrm{CHCl}_{3}, c 0.92\right) ; \mathrm{HRMS}$ (FAB, 3-NOBA, LiI) calcd for $\mathrm{C}_{47} \mathrm{H}_{48} \mathrm{O}_{9} \mathrm{Li},\left(\mathrm{M}+\mathrm{H}^{+}\right)$763.3458, obsd 763.3473.

Metathesis products $16 \mathrm{E} \& \mathrm{16Z}$. To a stirred solution of malonate derivative 15 (280 $\mathrm{mg}, 0.37 \mathrm{mmol})$ in dry $\mathrm{CH}_{2} \mathrm{Cl}_{2}(7 \mathrm{~mL})$, was added Grubbs I catalyst $(30 \mathrm{mg}, 0.037$ mmol). The resulting purple-colored solution was allowed to reflux under Ar for $8 \mathrm{~h}$. Volatiles were removed under reduced pressure and the crude residue was applied 
directly to an $\mathrm{SiO}_{2}$ column. Flash chromatography (15\% EtOAc-hexane) provided 16 $(185 \mathrm{mg}, 67 \%)$ as a mixture of geometric isomers $(\mathbf{1 6 E}: \mathbf{1 6 Z}=4: 1)$. Pure samples of the individual isomers (the cis isomer elutes first) could be obtained using careful chromatography with the same eluent. 16E (major isomer): ${ }^{1} \mathrm{H} \mathrm{NMR}\left(400 \mathrm{MHz}, \mathrm{CDCl}_{3}\right.$ ) $\delta 2.20(\mathrm{ddd}, J=5,10,14 \mathrm{~Hz}, 2 \mathrm{H}), 2.65(\mathrm{ddd}, J=2.5,10,12 \mathrm{~Hz}, 2 \mathrm{H}), 3.62(\mathrm{dt}, J=2.3$, $10 \mathrm{~Hz}, 2 \mathrm{H}), 3.70(\mathrm{t}, J=9 \mathrm{~Hz}, 2 \mathrm{H}), 3.68-3.72(\mathrm{~m}, 2 \mathrm{H}), 3.77-3.79(\mathrm{~m}, 4 \mathrm{H}), 3.87$ (dd, $J=3$, $9 \mathrm{~Hz}, 2 \mathrm{H}), 4.01$ (br d, $J=11 \mathrm{~Hz}, 2 \mathrm{H}), 4.60$ (s, 4H), 4.66 (d, $J=8 \mathrm{~Hz}, 2 \mathrm{H}), 4.68$ (d, $J=10$ $\mathrm{Hz}, 2 \mathrm{H}), 4.70(\mathrm{~d}, J=1.6 \mathrm{~Hz}, 2 \mathrm{H}), 4.74(\mathrm{~d}, J=12 \mathrm{~Hz}, 2 \mathrm{H}), 4.94(\mathrm{~d}, J=11 \mathrm{~Hz}, 2 \mathrm{H}), 5.09$ $(\mathrm{d}, J=12 \mathrm{~Hz}, 2 \mathrm{H}), 5.14(\mathrm{~s}, 4 \mathrm{H}), 5.15(\mathrm{~d}, J=12 \mathrm{~Hz}, 2 \mathrm{H}), 5.54(\mathrm{t}, J=2.8 \mathrm{~Hz}, 2 \mathrm{H}), 7.24-$ $7.36(\mathrm{~m}, 50 \mathrm{H}) ;{ }^{13} \mathrm{C} \mathrm{NMR}\left(100 \mathrm{MHz}, \mathrm{CDCl}_{3}\right) \delta 31.1,48.9,66.6,67.0,67.1,69.4,72.1$, 72.8, 74.5, 75.3, 78.6, 80.1, 96.9, 127.5 (2C), 127.6, 127.8, 127.9, 128.1, 128.2, 128.3 (2C), $128.4,128.5,135.3,135.4,138.2,138.3,138.4,168.7,169.1 ;[\alpha]^{23}{ }_{D}+29.0$ $\left(\mathrm{CHCl}_{3}, c\right.$ 1.0); HRMS (FAB, 3-NOBA, LiI) calcd for $\mathrm{C}_{92} \mathrm{H}_{92} \mathrm{O}_{18} \mathrm{Li},\left(\mathrm{M}+\mathrm{Li}^{+}\right)$ 1491.6445, obsd 1491.6471.

$16 Z$ (minor isomer): $\left.{ }^{1} \mathrm{H} \mathrm{NMR} \mathrm{(400} \mathrm{MHz}, \mathrm{CDCl}_{3}\right) \delta 2.20$, (ddd, $J=5,10,14 \mathrm{~Hz}, 2 \mathrm{H}$ ), $2.65(\mathrm{ddd}, J=2.5,10,12 \mathrm{~Hz}, 2 \mathrm{H}), 3.62(\mathrm{dt}, J=2.3,10 \mathrm{~Hz}, 2 \mathrm{H}), 3.70(\mathrm{t}, J=9 \mathrm{~Hz}, 2 \mathrm{H})$, 3.74-3.80 (m, 4H), $3.85(\mathrm{dd}, J=3,9 \mathrm{~Hz}, 2 \mathrm{H}), 3.88(\mathrm{dd}, J=5,12 \mathrm{~Hz}, 2 \mathrm{H}), 4.05(\mathrm{dd}, J=$ $3,12 \mathrm{~Hz}, 2 \mathrm{H}), 4.59(\mathrm{~s}, 4 \mathrm{H}), 4.64(\mathrm{~d}, J=5 \mathrm{~Hz}, 2 \mathrm{H}), 4.67$ (d, $J=7 \mathrm{~Hz}, 2 \mathrm{H}), 4.72(\mathrm{~d}, J=12$ $\mathrm{Hz}, 2 \mathrm{H}), 4.75(\mathrm{~d}, J=1.6 \mathrm{~Hz}, 2 \mathrm{H}), 4.94(\mathrm{~d}, J=10 \mathrm{~Hz}, 2 \mathrm{H}), 5.06(\mathrm{~d}, J=12 \mathrm{~Hz}, 2 \mathrm{H}), 5.10$ $(\mathrm{d}, J=3 \mathrm{~Hz}, 4 \mathrm{H}), 5.15(\mathrm{~d}, J=12 \mathrm{~Hz}, 2 \mathrm{H}), 5.48$ (t, $J=4 \mathrm{~Hz}, 2 \mathrm{H}), 7.20-7.41(\mathrm{~m}, 50 \mathrm{H})$; ${ }^{13} \mathrm{C} \mathrm{NMR}\left(100 \mathrm{MHz}, \mathrm{CDCl}_{3}\right) \delta 31.1,49.0,62.8,67.0,67.1,69.3,72.0,72.7,74.6,75.2$, 78.5, 80.0, 97.2, 127.5 (2C), 127.6, 127.8, 127.9, 128.0, 128.2 (2C), 128.3, 128.4, 128.5 (2C), 135.3, 135.4, 138.2, 138.3, 138.4, 168.7, 169.0; $[\alpha]^{23}{ }_{\mathrm{D}}+23.3\left(\mathrm{CHCl}_{3}, c 0.85\right)$.

\section{Bivalent 6-deoxy-6-(2'-malonyl)-mannopyranoside mimic, tetrakis(ammonium) salt}

(17). A solution of $\mathbf{1 6 E}(185 \mathrm{mg}, 0.12 \mathrm{mmol})$ in $2: 1$ isopropyl alcohol/ethyl acetate (6 and $3 \mathrm{~mL}$ respectively) was stirred with $20 \% \mathrm{Pd}(\mathrm{OH})_{2} / \mathrm{C}(32 \mathrm{mg})$ overnight at room temperature, under balloon pressure of hydrogen. Filtration through Celite, followed by addition of aqueous $\mathrm{NH}_{4} \mathrm{HCO}_{3}(50 \mathrm{mM}, 5 \mathrm{~mL})$ gave $17(50 \mathrm{mg}, 71 \%)$ after evaporation and thorough drying, in vacuo: ${ }^{1} \mathrm{H}$ NMR $\left(400 \mathrm{MHz}, \mathrm{D}_{2} \mathrm{O}\right) \delta$ 1.56-1.65 (m, 4H), 1.94 (dd, $J=10,14 \mathrm{~Hz}, 2 \mathrm{H}), 2.45$ (br d $J=14 \mathrm{~Hz}, 2 \mathrm{H}), 3.45$ (t, $J=9 \mathrm{~Hz}, 2 \mathrm{H}), 3.47-3.53$ (m, $6 \mathrm{H}), 3.70-3.74(\mathrm{~m}, 2 \mathrm{H}), 3.72(\mathrm{dd}, J=3.5 \mathrm{~Hz}, 9 \mathrm{~Hz}, 2 \mathrm{H}), 3.88(\mathrm{dd}, J=1.5,3 \mathrm{~Hz}, 2 \mathrm{H})$, 4.77 (br s, 2H); ${ }^{13} \mathrm{C}$ NMR (400 MHz, $\left.\mathrm{D}_{2} \mathrm{O}\right) \delta$ 25.3, 31.2, 49.8, 67.3, 70.0 (2C), 70.3, 
70.8, 99.3, 175.6, 176; $[\alpha]^{23}{ }_{\mathrm{D}}+47.2$ [50\% MeOH (aq), $c$ 1.00]; HRMS (FAB, Gly, negative ion mode) calcd for $\mathrm{C}_{22} \mathrm{H}_{33} \mathrm{O}_{18},\left({\left.\mathrm{M}-\mathrm{H}^{-}\right)}^{-} 585.1667\right.$, obsd 585.1679.

Metathesis products $18 \mathrm{E} \& \mathbf{1 8 Z}$. To a solution of alcohol $13(520 \mathrm{mg}, 1.06 \mathrm{mmol})$ in dry $\mathrm{CH}_{2} \mathrm{Cl}_{2}(5 \mathrm{~mL})$ was added Grubbs I catalyst $(87 \mathrm{mg}, 0.106 \mathrm{mmol})$, and the resulting purple-colored solution allowed to reflux for $8 \mathrm{~h}$. Filtration (Celite), evaporation of the volatiles and $\mathrm{SiO}_{2}$ flash chromatography $(40 \rightarrow 60 \%$ EtOAc-hexane) afforded 18 (428 $\mathrm{mg}, 84 \%$ ) as a separable mixture of geometric isomers $[\mathrm{E} / \mathrm{Z}=4: 1]$. 18E (major isomer): ${ }^{1} \mathrm{H}$ NMR (400 MHz, $\mathrm{CDCl}_{3}$ ) $\delta 2.14$ (app t, $J=6 \mathrm{~Hz}, 2 \mathrm{H}$ ), 3.64-3.68 (m, 2H), 3.75-3.81 (m, 2H), 3.83-3.86 (m, 2H), 3.83 (app t, $J=2 \mathrm{~Hz}, 2 \mathrm{H}$ ), 3.91 (br d, $J=11 \mathrm{~Hz}, 2 \mathrm{H}$ ), 3.95 (dd, $J=3,9 \mathrm{~Hz}, 2 \mathrm{H}), 3.98(\mathrm{t}, J=9 \mathrm{~Hz}, 2 \mathrm{H}), 4.11(\mathrm{br} \mathrm{d}, J=11 \mathrm{~Hz}, 2 \mathrm{H}), 4.65(\mathrm{br} \mathrm{s}, 4 \mathrm{H}$ ), $4.66(\mathrm{~d}, J=11 \mathrm{~Hz}, 2 \mathrm{H}), 4.69(\mathrm{~d}, J=12 \mathrm{~Hz}, 2 \mathrm{H}), 4.79(\mathrm{~d}, J=12 \mathrm{~Hz}, 2 \mathrm{H}), 4.85(\mathrm{~d}, J=1.6$ $\mathrm{Hz}, 2 \mathrm{H}), 4.95(\mathrm{~d}, J=11 \mathrm{~Hz}, 2 \mathrm{H}), 5.68(\mathrm{t}, J=3 \mathrm{~Hz}, 2 \mathrm{H}), 7.26-7.38(\mathrm{~m}, 30 \mathrm{H}) ;{ }^{13} \mathrm{C} \mathrm{NMR}$ $\left(100 \mathrm{MHz}, \mathrm{CDCl}_{3}\right) \delta 62.3,66.9,72.2,72.3,72.9,74.6,74.8,75.3,80.2,97.6,127.5$, 127.7 (2C), 127.8, 128.1, $128.3(2 \mathrm{C}), 128.4,128.5,138.1,138.2,138.4 ;[\alpha]^{23}{ }_{\mathrm{D}}+44.7$ $\left(\mathrm{CHCl}_{3}, c\right.$ 1.14); HRMS (FAB 3-NOBA, LiI) calcd for $\mathrm{C}_{58} \mathrm{H}_{64} \mathrm{O}_{12} \mathrm{Li}\left(\mathrm{M}+\mathrm{Li}^{+}\right)$959.4558, obsd 959.4553.

18Z: ${ }^{1} \mathrm{H}$ NMR (400 MHz, $\mathrm{CDCl}_{3}$ ) \& 2.59 (br s, 2H), 3.68-3.70 (m, 2H), 3.72-3.79 (m, 2H), 3.82-3.89 (m, 4H), 3.92-3.97 (m, 4H), 4.00 (dd, $J=5,13 \mathrm{~Hz}, 2 \mathrm{H}), 4.19$ (dd, $J=4$, $12 \mathrm{~Hz}, 2 \mathrm{H}), 4.65$ (br s, 4H), $4.66(\mathrm{~d}, J=11 \mathrm{~Hz}, 2 \mathrm{H}), 4.71(\mathrm{~d}, J=12 \mathrm{~Hz}, 2 \mathrm{H}), 4.79(\mathrm{~d}, J=$ $12 \mathrm{~Hz}, 2 \mathrm{H}), 4.86(\mathrm{~d}, J=1.5 \mathrm{~Hz}, 2 \mathrm{H}), 4.95(\mathrm{~d}, J=11 \mathrm{~Hz}, 2 \mathrm{H}), 5.66(\mathrm{t}, J=4 \mathrm{~Hz}, 2 \mathrm{H})$, 7.27-7.39 (m, $30 \mathrm{H})$; ${ }^{13} \mathrm{C} \mathrm{NMR} \mathrm{(100} \mathrm{MHz,} \mathrm{CDCl}_{3}$ ) $\delta$ 62.2, 62.3, 72.1, 72.6, 72.8, 74.6, 74.9, 75.1, 80.1, 97.1, 127.5, 127.6, 127.7, 127.8, 128.0, 128.2, 128.3 (2C), 128.8, 138.1, $138.2,138.4 ;[\alpha]^{23}{ }_{\mathrm{D}}+47.3\left(\mathrm{CHCl}_{3}, c 0.93\right)$.

Bis-triflate 19. To a solution of $18 \mathrm{E}(260 \mathrm{mg}, 0.27 \mathrm{mmol})$ and 2,6-di-tert-butyl-4methylpyridine $(280 \mathrm{mg}, 1.37 \mathrm{mmol})$ in $\mathrm{CH}_{2} \mathrm{Cl}_{2}(4 \mathrm{~mL})$, was added slowly trifluoromethanesulfonic anhydride $(335 \mu \mathrm{L}, 2.0 \mathrm{mmol})$ at $-40{ }^{\circ} \mathrm{C}$. The reaction was held at that temperature for $2.5 \mathrm{~h}$, then diluted with $\mathrm{Et}_{2} \mathrm{O}$. The organic layer was sequentially washed with saturated aqueous $\mathrm{NH}_{4} \mathrm{Cl}$ and saturated aqueous $\mathrm{NaHCO}_{3}$, then dried $\left(\mathrm{MgSO}_{4}\right)$, filtered and evaporated. Flash $\mathrm{SiO}_{2}$ chromatography (35\% $\mathrm{Et}_{2} \mathrm{O}$-hexane) afforded 19 (280 mg, 84\%) as a colorless oil: ${ }^{1} \mathrm{H}$ NMR (400 MHz, $\left.\mathrm{CDCl}_{3}\right) \delta 3.81$ (dd, $J$ $=2,3 \mathrm{~Hz}, 2 \mathrm{H}), 3.83-3.85(\mathrm{~m}, 4 \mathrm{H}), 3.88-3.97(\mathrm{~m}, 8 \mathrm{H}), 4.09$ (br d, $J=10 \mathrm{~Hz}, 2 \mathrm{H}), 4.52-$ $4.63(\mathrm{~m}, 4 \mathrm{H}), 4.57(\mathrm{~d}, J=11 \mathrm{~Hz}, 2 \mathrm{H}), 4.61(\mathrm{~d}, J=2 \mathrm{~Hz}, 4 \mathrm{H}), 4.66(\mathrm{~d}, J=12 \mathrm{~Hz}, 2 \mathrm{H})$, 
$4.73(\mathrm{~d}, J=12 \mathrm{~Hz}, 2 \mathrm{H}), 4.84(\mathrm{~d}, J=1.7 \mathrm{~Hz}, 2 \mathrm{H}), 4.96(\mathrm{~d}, J=11 \mathrm{~Hz}, 2 \mathrm{H}), 5.64(\mathrm{t}, J=3$ $\mathrm{Hz}, 2 \mathrm{H}), 7.25-7.35(\mathrm{~m}, 15 \mathrm{H}) ;{ }^{13} \mathrm{C} \mathrm{NMR}\left(100 \mathrm{MHz}, \mathrm{CDCl}_{3}\right) \delta$ 67.2, 70.0, 72.1, 72.8, 73.6, 74.3, 75.3, 75.5, 80.1, 97.2, $118.5(\mathrm{q}, J=320 \mathrm{~Hz}), 127.7,127.8,128.1,128.2$,

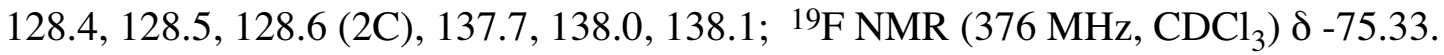

Bis displacement product 20: To a magnetically stirred solution of dibenzyl methylphosphonate $(250 \mathrm{mg}, 0.90 \mathrm{mmol})$ in THF $(4 \mathrm{~mL})$ at $-78^{\circ} \mathrm{C}$ was added slowly a solution of $n$-BuLi $(0.6 \mathrm{~mL}$, of $1.5 \mathrm{M}$ in hexane, $0.90 \mathrm{mmol})$, followed by $30 \mathrm{~min}$ stirring at that temperature. A solution of bis-triflate (19) $(220 \mathrm{mg}, 018 \mathrm{mmol})$ in THF (2 $\mathrm{mL})$ was then added, dropwise, via cannula, and the resulting reaction mixture stirred for $1 \mathrm{~h}$ at $78{ }^{\circ} \mathrm{C}$. The reaction was then quenched with saturated aqueous $\mathrm{NH}_{4} \mathrm{Cl}$. Following dilution with EtOAc $(50 \mathrm{~mL})$, the organic layer was washed sequentially with $\mathrm{NH}_{4} \mathrm{Cl}$ (aq), water and brine. Drying $\left(\mathrm{MgSO}_{4}\right)$, filtration, evaporation and $\mathrm{SiO}_{2}$ flash chromatography (EtOAc) provided 20 (200 $\mathrm{mg}, 75 \%$ ) as a colorless oil. ${ }^{1} \mathrm{H}$ NMR (500 $\mathrm{MHz}, \mathrm{CDCl}_{3}$ ) $\delta 1.69-1.87$ (m, 4H), 2.04-2.23 (m, 4H), 3.49 (dt, $\left.J=2.4,9 \mathrm{~Hz}, 2 \mathrm{H}\right), 3.64$ (t, $J=9 \mathrm{~Hz}, 2 \mathrm{H}), 3.70-3.80(\mathrm{~m}, 4 \mathrm{H}) 3.86(\mathrm{dd}, J=3,9 \mathrm{~Hz}, 2 \mathrm{H}), 3.99(\mathrm{br} \mathrm{d}, J=11 \mathrm{~Hz}$, 2H), $4.56(\mathrm{~d}, J=11 \mathrm{~Hz}, 2 \mathrm{H}), 4.61(\mathrm{~s}, 4 \mathrm{H}), 4.69(\mathrm{~d}, J=12 \mathrm{~Hz}, 2 \mathrm{H}), 4.75(\mathrm{~d}, J=12 \mathrm{~Hz}$, 2H), $4.77(\mathrm{~d}, J=1.5 \mathrm{~Hz}, 2 \mathrm{H}), 4.90(\mathrm{~d}, J=11 \mathrm{~Hz}, 2 \mathrm{H}), 4.95(\mathrm{~d}, J=12 \mathrm{~Hz}, 2 \mathrm{H}), 4.96(\mathrm{~d}, J$ $=12 \mathrm{~Hz}, 2 \mathrm{H}), 5.00(\mathrm{dd}, J=2,9 \mathrm{~Hz}, 2 \mathrm{H}), 5.03(\mathrm{dd}, J=2,9 \mathrm{~Hz}, 2 \mathrm{H}), 5.58(\mathrm{t}, J=2.7 \mathrm{~Hz}$, 2H), 7.24-7.35 (m, 50H); $\left.{ }^{13} \mathrm{C} \mathrm{NMR} \mathrm{(125} \mathrm{MHz,} \mathrm{CDCl}_{3}\right) \delta 22.2(\mathrm{~d}, J=141 \mathrm{~Hz}), 24.6$ (d, $J$ $=4 \mathrm{~Hz}), 66.5,66.9,67.0,71.3(\mathrm{~d}, J=18 \mathrm{~Hz}), 72.1,72.8,74.6,75.3,78.1,80.3,97.1$, 127.5 (2C), 127.6 (2C), 127.8 (3C), 127.9, 128.0, 128.2 (2C), 128.3, 128.5, 136.4 (d, $J=$ $6 \mathrm{~Hz}), 138.2(2 \mathrm{C}), 138.4 ;{ }^{31} \mathrm{P} \mathrm{NMR}\left(202 \mathrm{MHz}, \mathrm{CDCl}_{3}\right) \delta 33.17 ;[\alpha]^{23}{ }_{\mathrm{D}}+27.7\left(\mathrm{CHCl}_{3}\right.$, c 0.26); HRMS (FAB 3-NOBA) calcd for $\mathrm{C}_{88} \mathrm{H}_{94} \mathrm{O}_{16} \mathrm{P}_{2}\left(\mathrm{M}+\mathrm{H}^{+}\right)$1469.6098, obsd 1469.6147.

\section{Bivalent 6-deoxy-6-phosphonomethyl-mannopyranose mimic, tetrakis(ammonium)}

salt (21). A solution of protected, bivalent phosphonate 20 (200 mg, $0.14 \mathrm{mmol})$ in isopropanol/ ethyl acetate ( 8 and $4 \mathrm{~mL}$ respectively) containing $20 \% \mathrm{Pd}(\mathrm{OH})_{2} / \mathrm{C}(38$ $\mathrm{mg}$ ) was stirred under a balloon pressure of hydrogen, at room temperature, overnight. Following filtration through Celite and washing of the filter cake with isopropanol, a solution of $50 \mathrm{mM} \mathrm{NH}_{4} \mathrm{HCO}_{3}(8 \mathrm{~mL})$ was added to the filtrate. Removal of the volatiles in vacuo and further drying on the high vacuum gave 21 (54 mg, 63\%): ${ }^{1} \mathrm{H}$ NMR (400 $\left.\mathrm{MHz}, \mathrm{D}_{2} \mathrm{O}\right) \delta$ 1.53-1.72 (m, 8H), 1.81-1.91 (m, 2H), 2.05-2.12 (m, 2H), 3.50-3.57 (m, 
$6 \mathrm{H}), 3.72-3.77(\mathrm{~m}, 4 \mathrm{H}), 3.93(\mathrm{dd}, J=1.6,3 \mathrm{~Hz}, 2 \mathrm{H}), 4.82(\mathrm{~d}, J=1.2 \mathrm{~Hz}, 2 \mathrm{H}) ;{ }^{13} \mathrm{C}$ NMR (125 MHz, $\left.\mathrm{D}_{2} \mathrm{O}\right) \delta 23.9(\mathrm{~d}, J=134 \mathrm{~Hz}), 25.1,25.4,67.4,70.1$ (2C), 70.5, 72.6, 99.6; ${ }^{31} \mathrm{P}$ NMR (202 MHz, $\left.\mathrm{D}_{2} \mathrm{O}\right) \delta$ 25.39; $[\alpha]^{23} \mathrm{D}+40.2[50 \% \mathrm{MeOH}(\mathrm{aq}), c$ 0.66]; HRMS (FAB, Gly.) calcd for $\mathrm{C}_{18} \mathrm{H}_{36} \mathrm{O}_{16} \mathrm{P}_{2},\left(\mathrm{M}+\mathrm{H}^{+}\right)$571.1557, obsd 571.1535.

\section{References:}

1. (a) Julian, R. R.; May, J. A.; Stoltz, B. M.; Beauchamp, J. L. J. Am. Chem. Soc. 2003, 125, 4478-4486; (b) Wolfe, S.; Ro, S.; Kim, C.-K.; Shi, Z. Can. J. Chem. 2001, 79, 1238-1258.

2. Mikkelsen, L. M.; Krintel, S. L.; Jimenez-Barbero, J.; Skrydstrup, T. J. Org. Chem. 2002, 67, 6297-6308 


\section{Spectral Data}

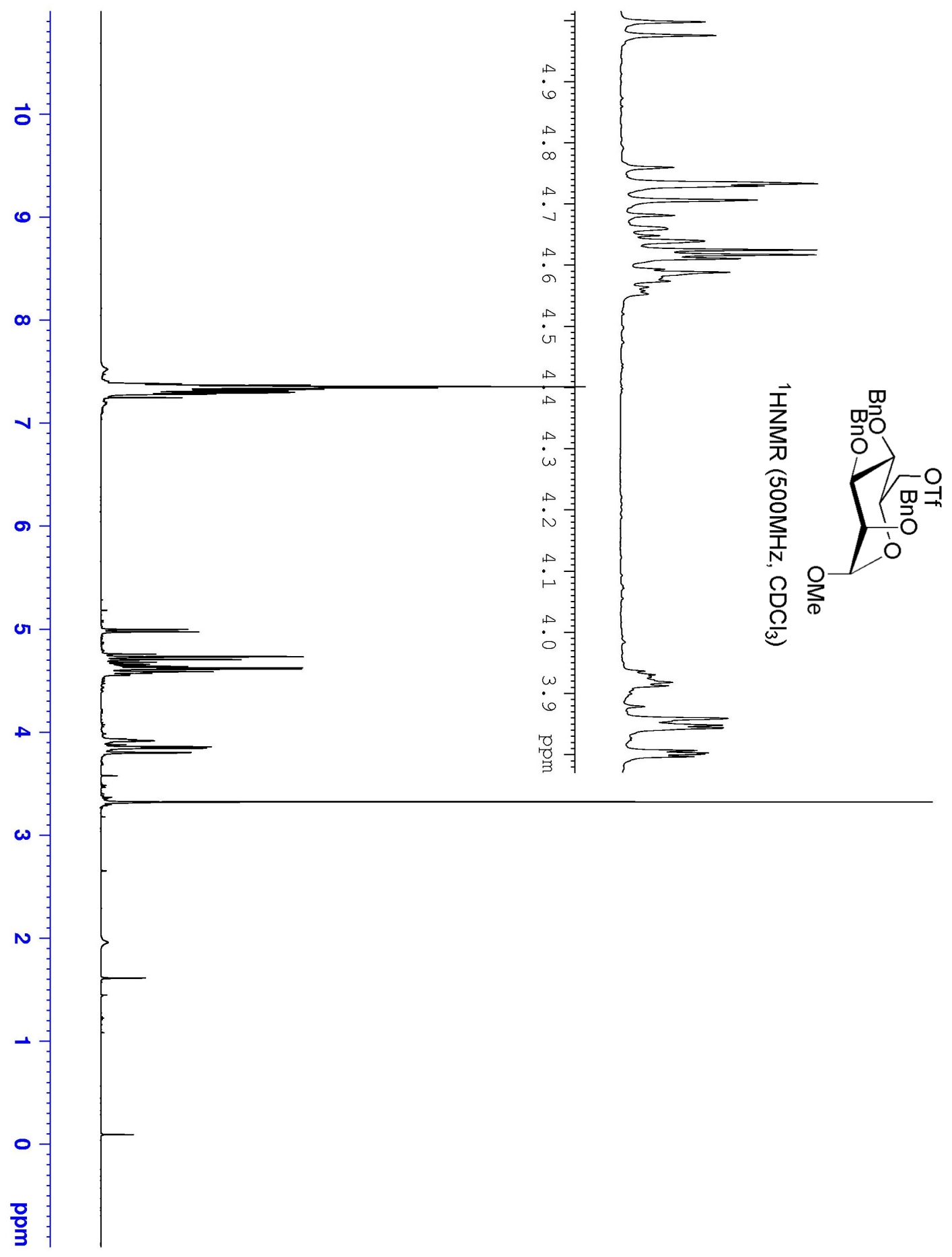




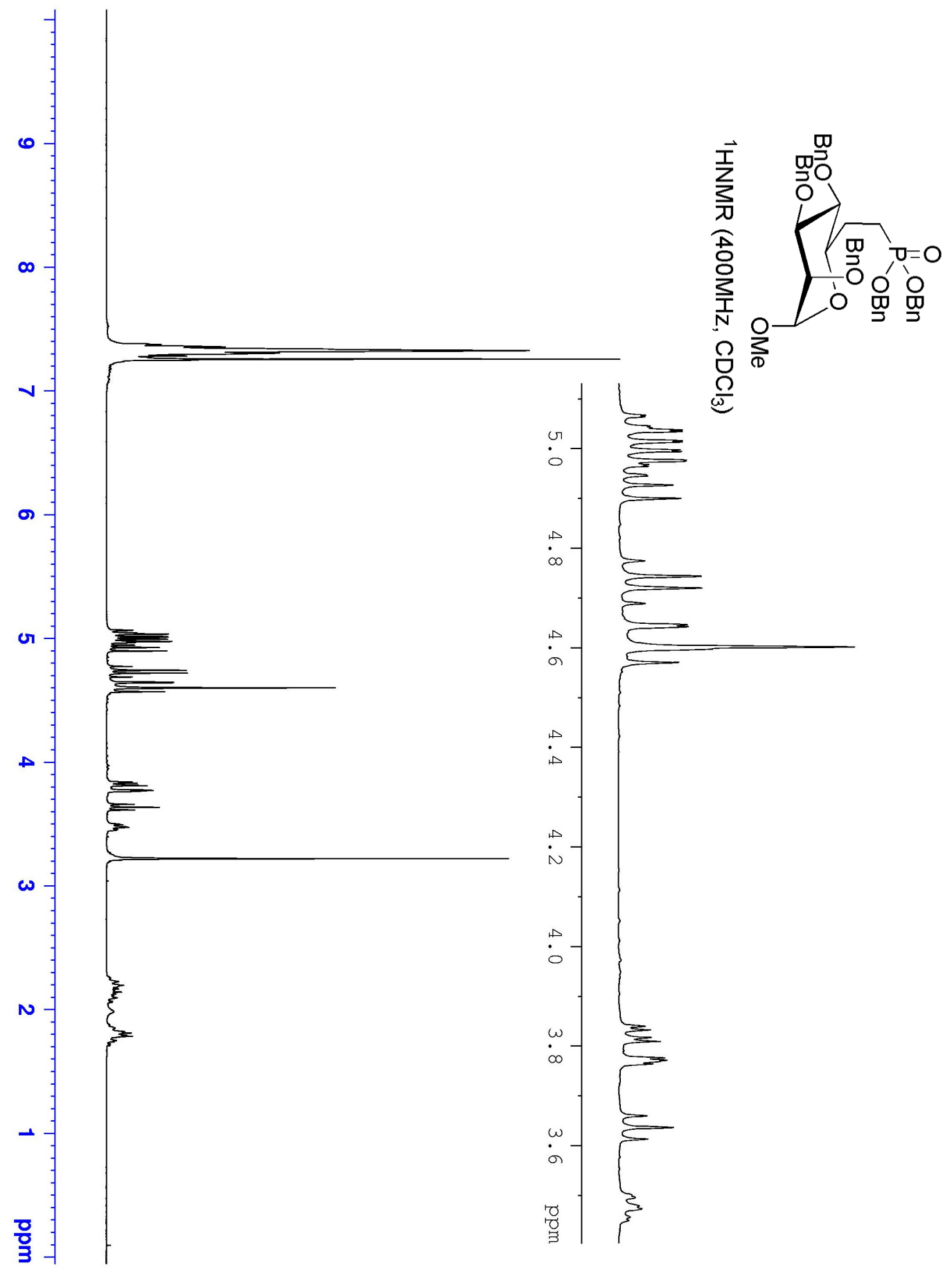




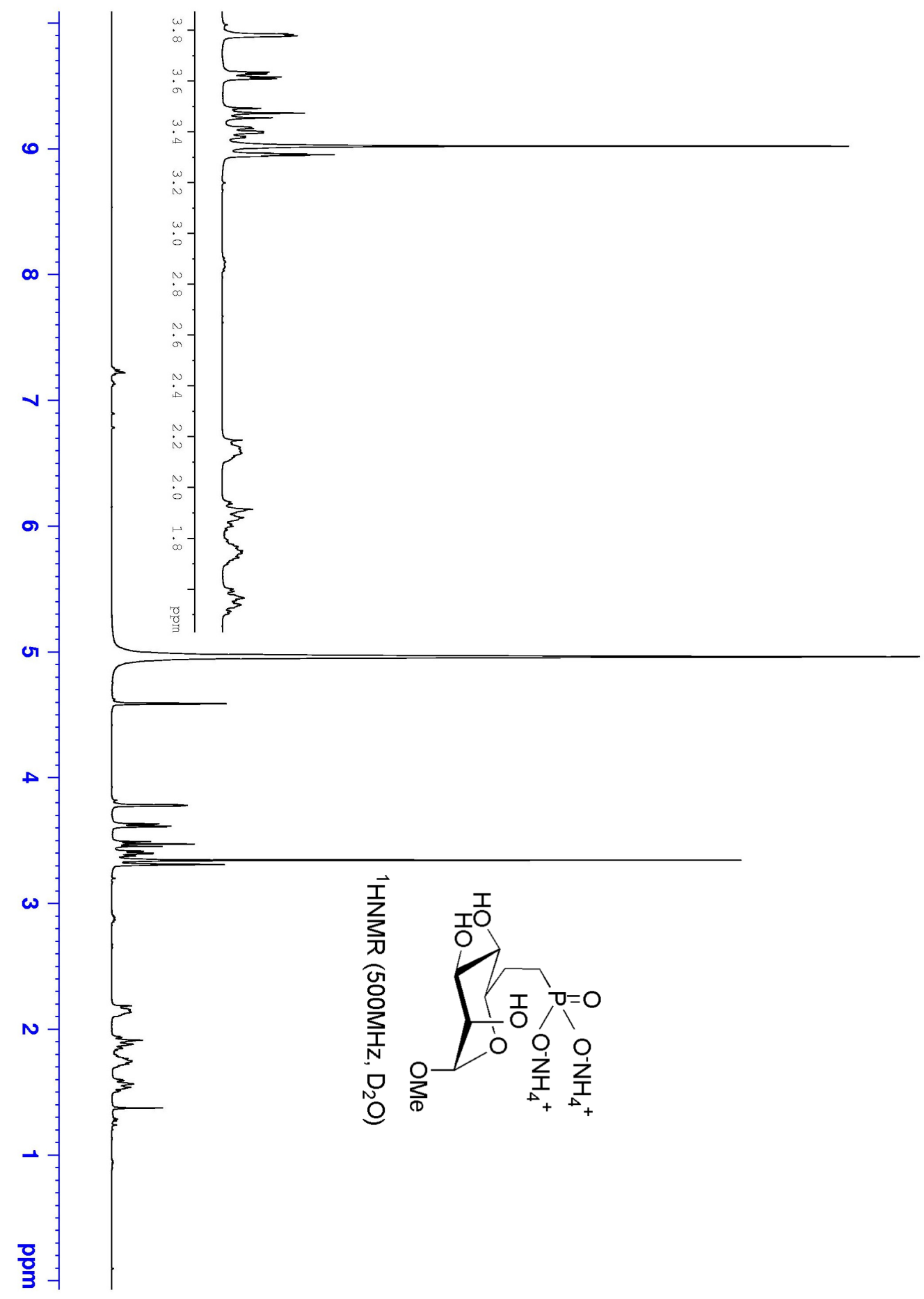




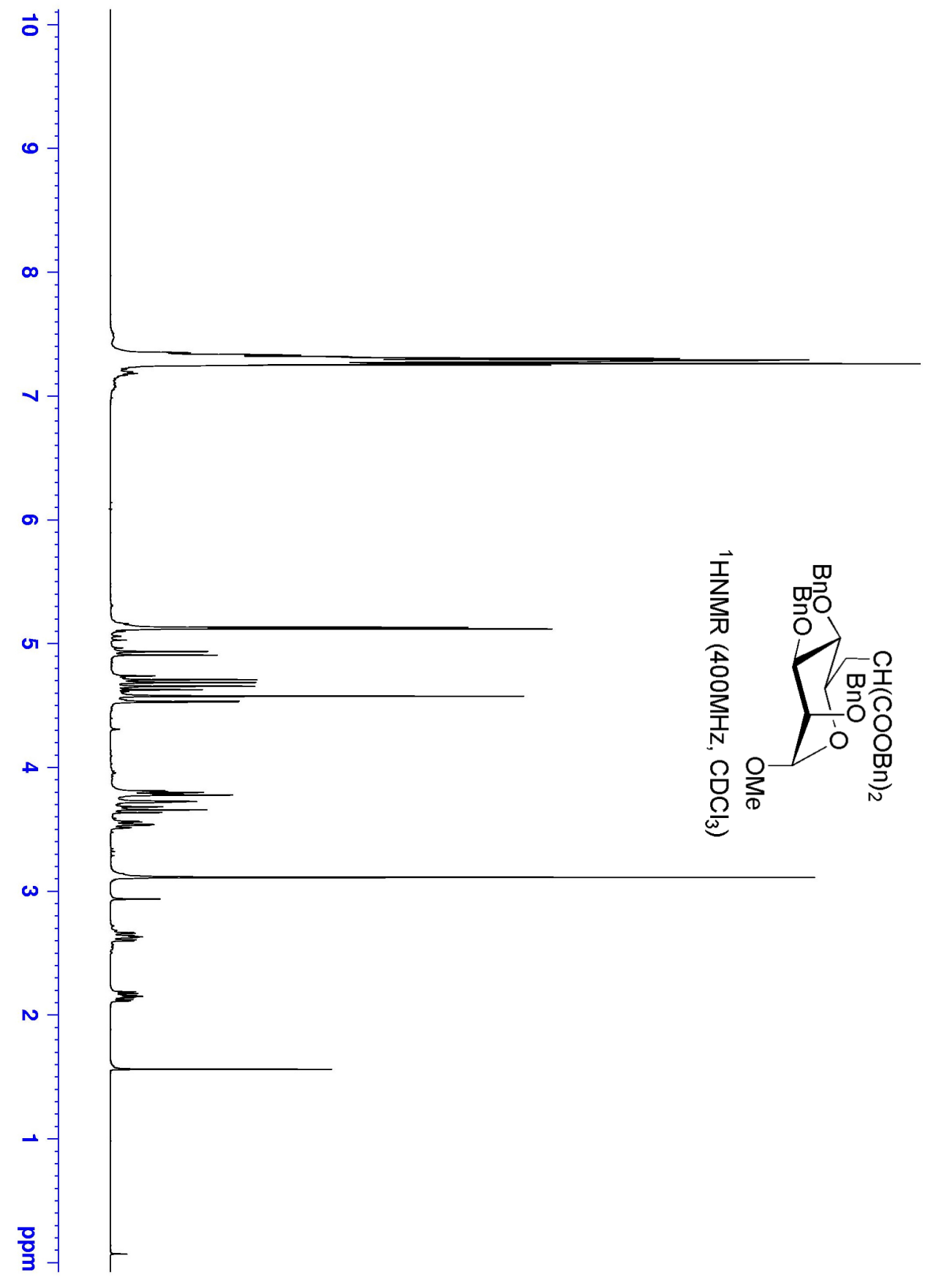




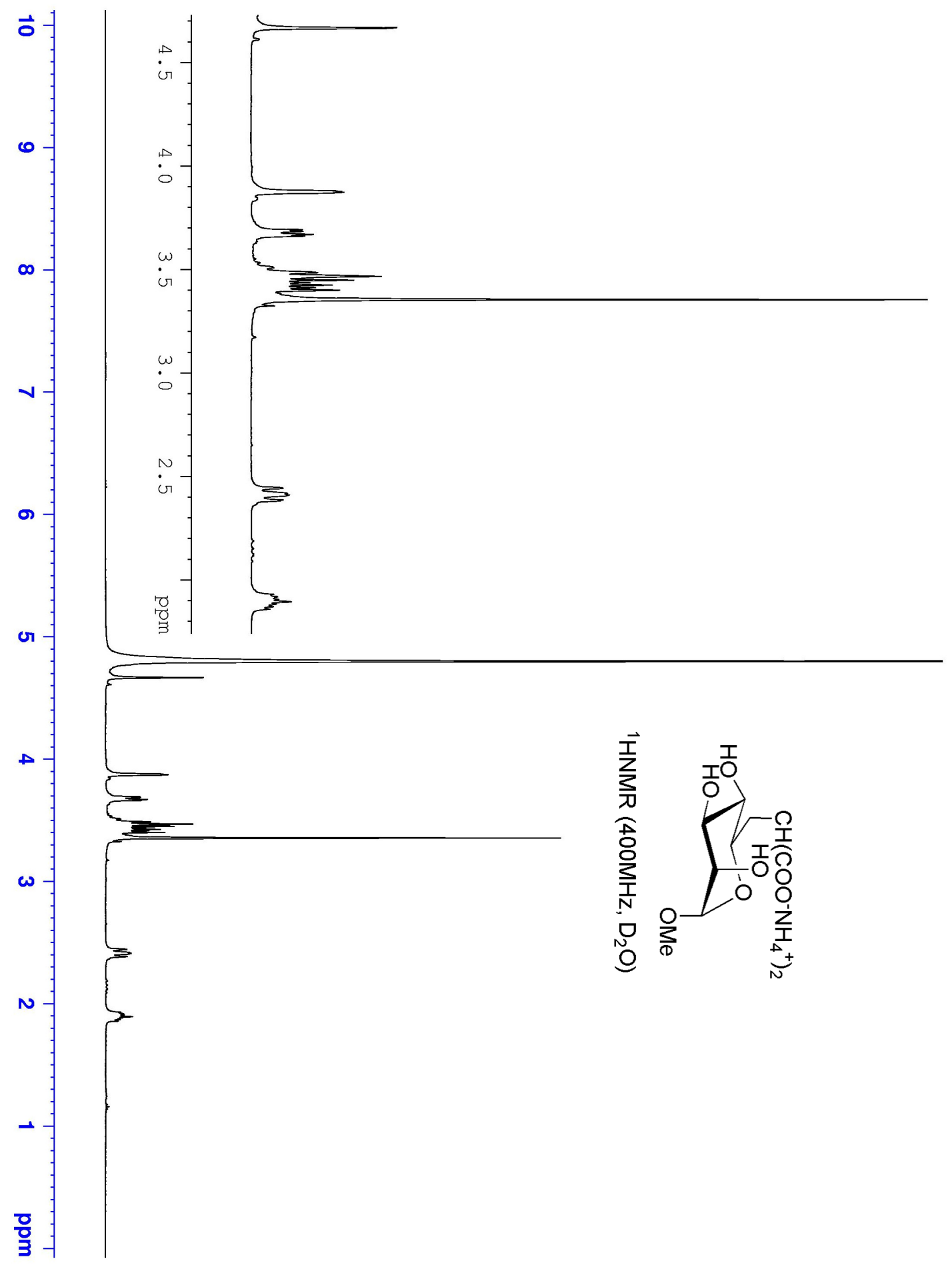

15 


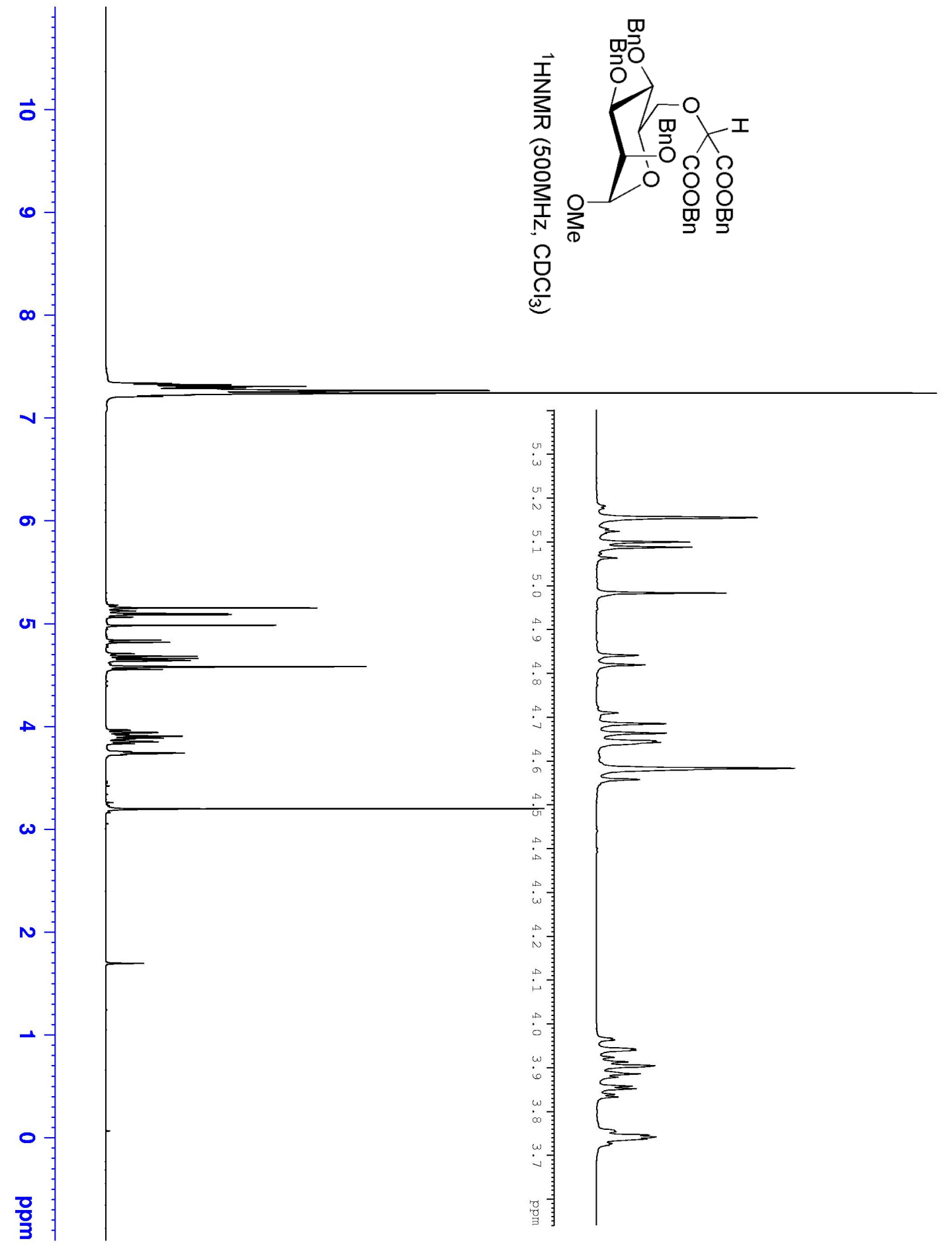




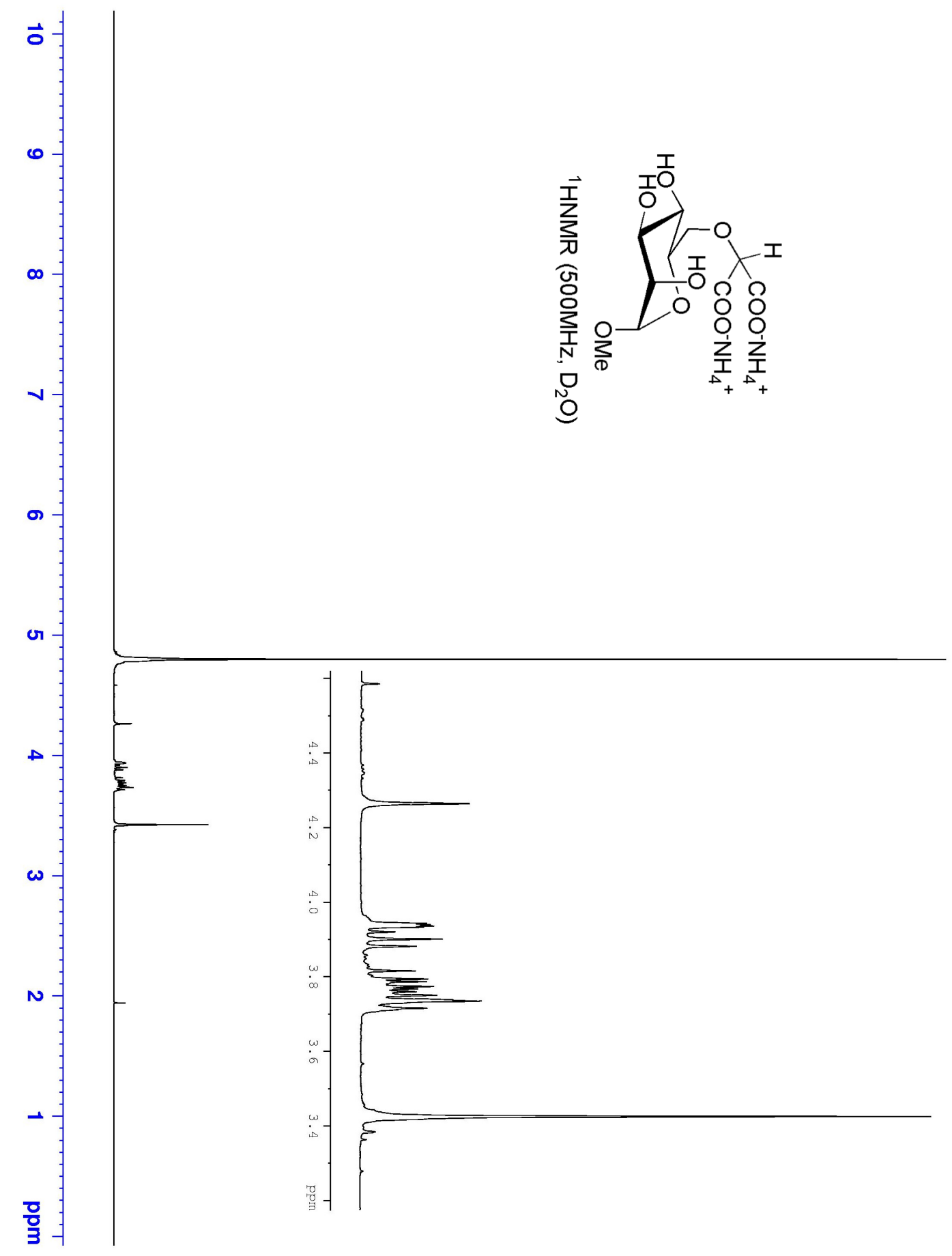




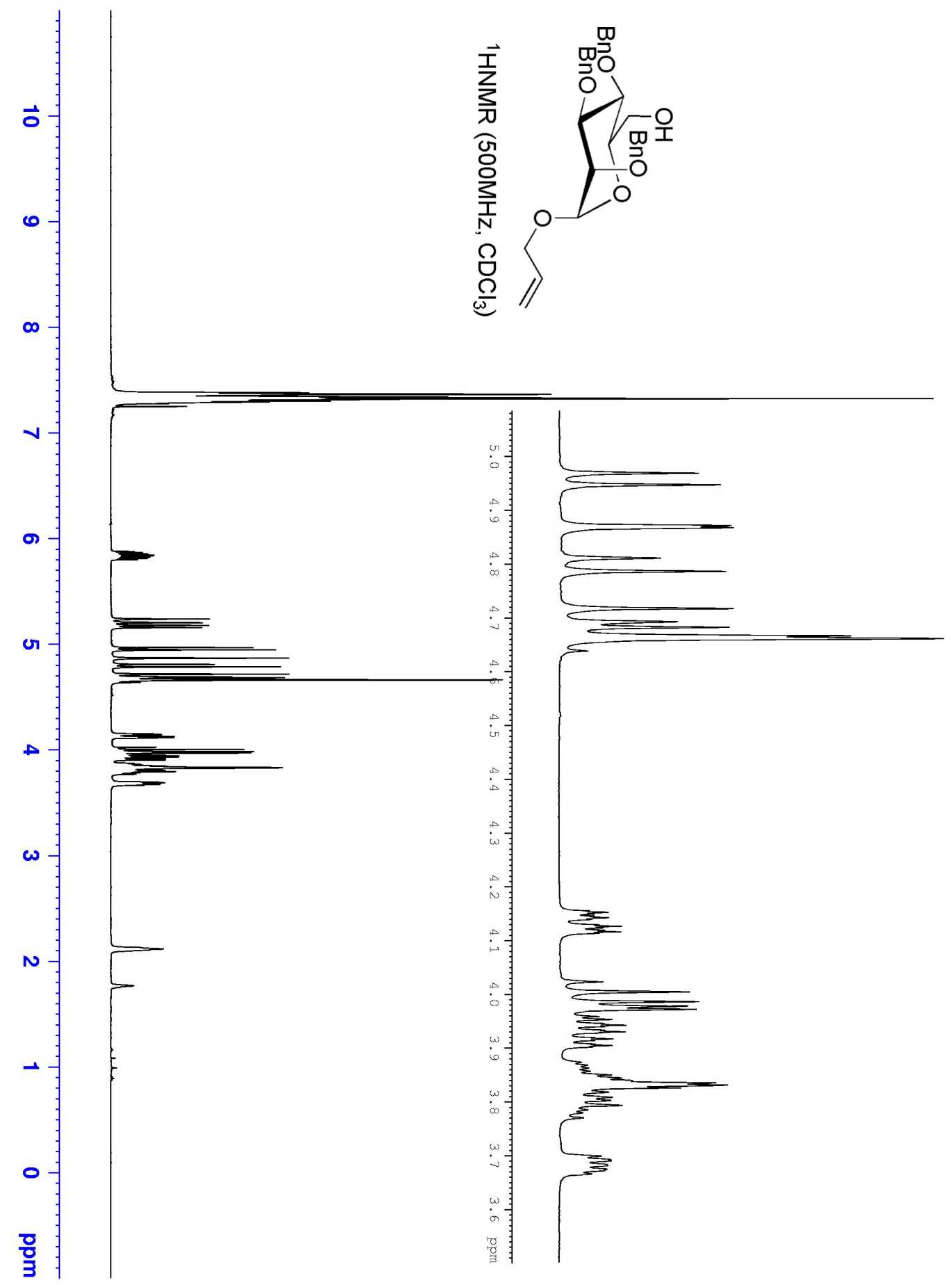




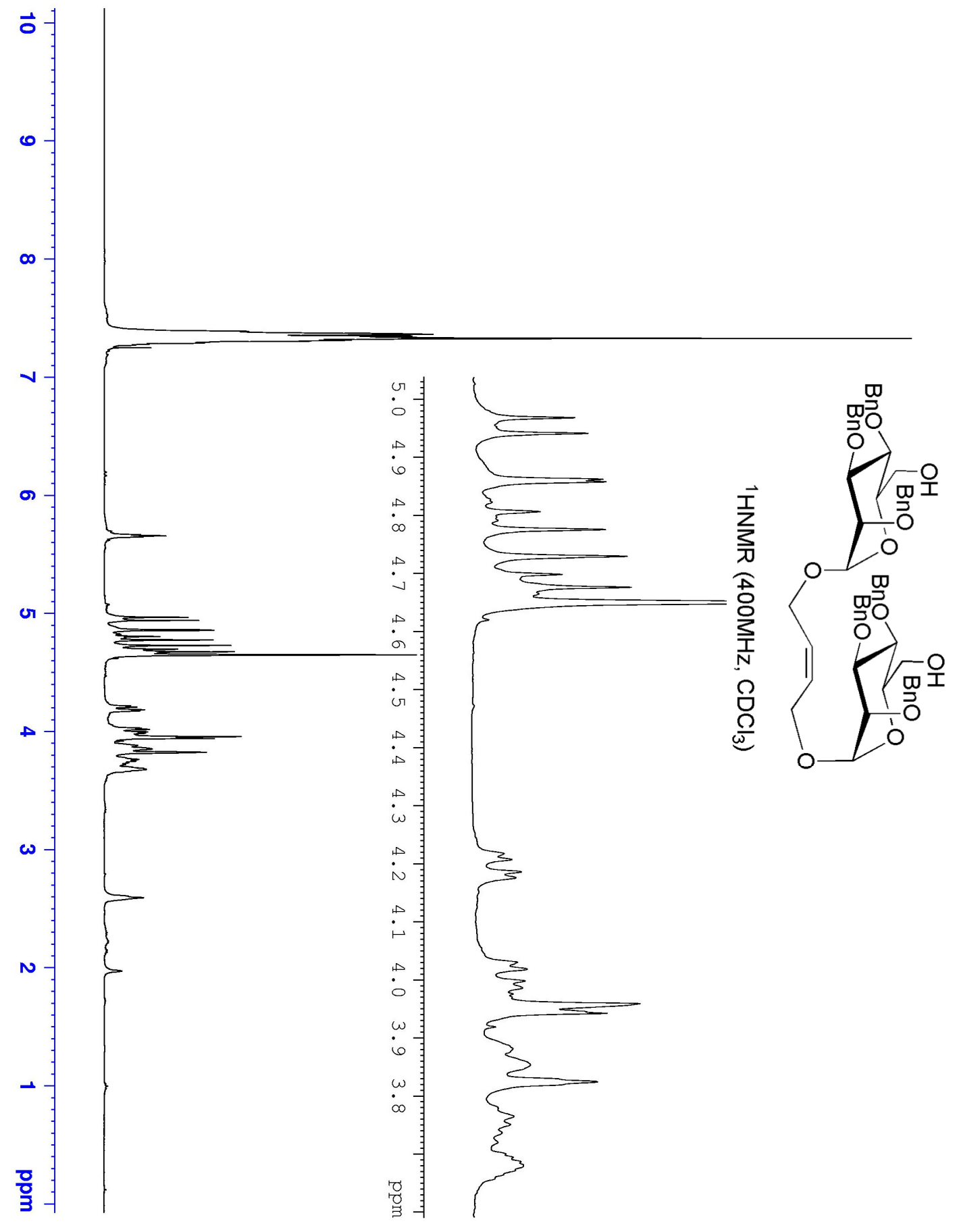




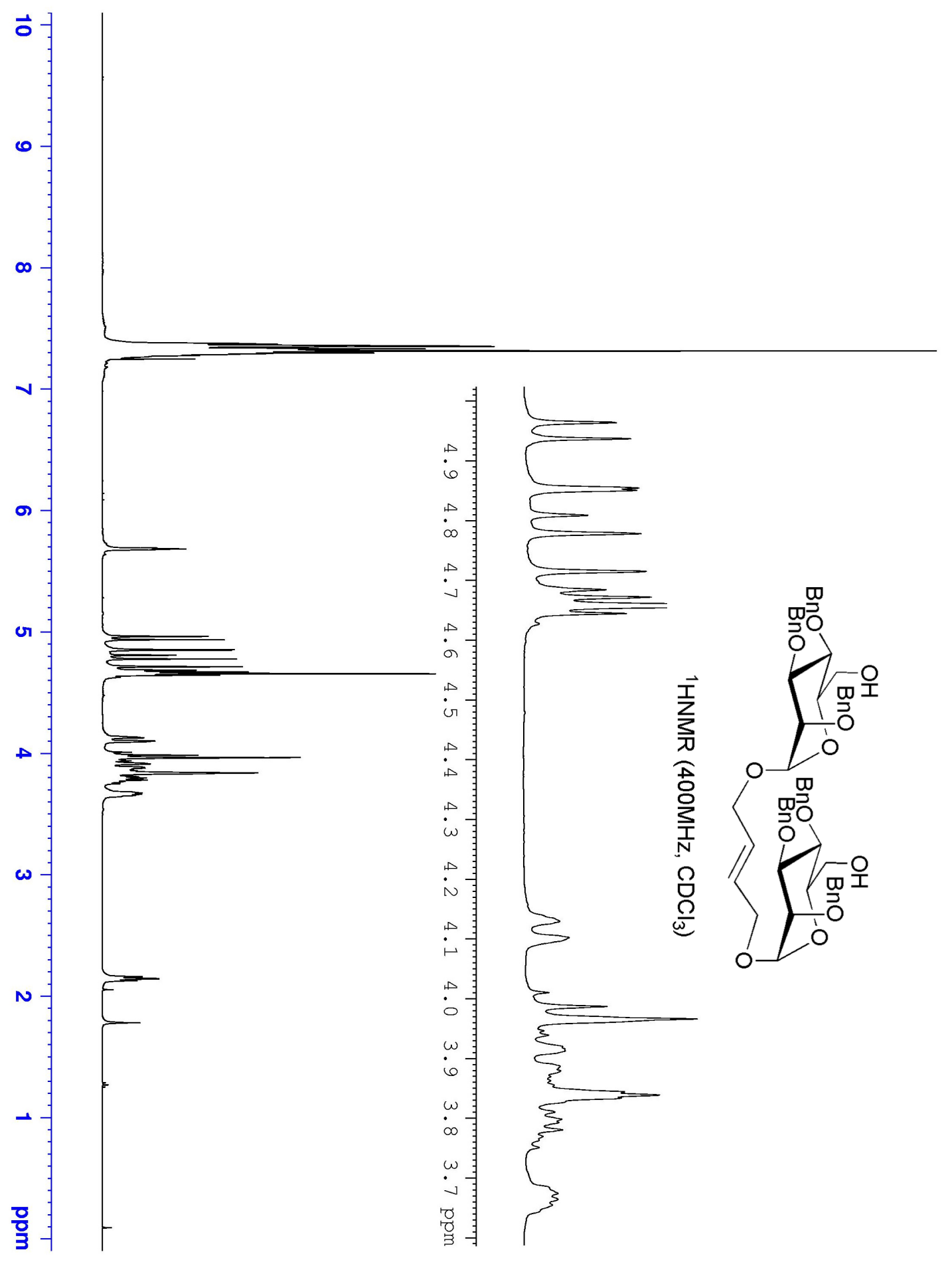




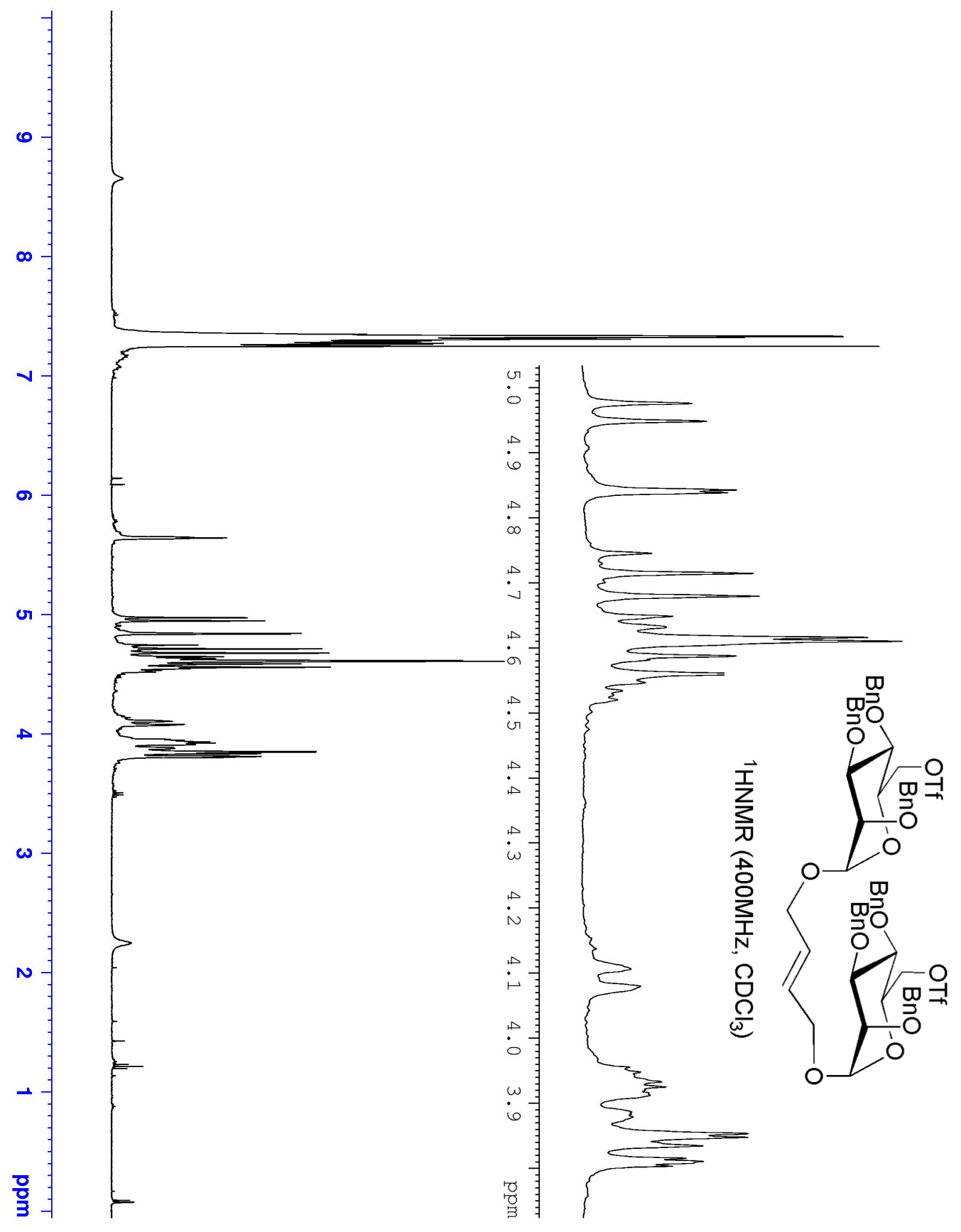




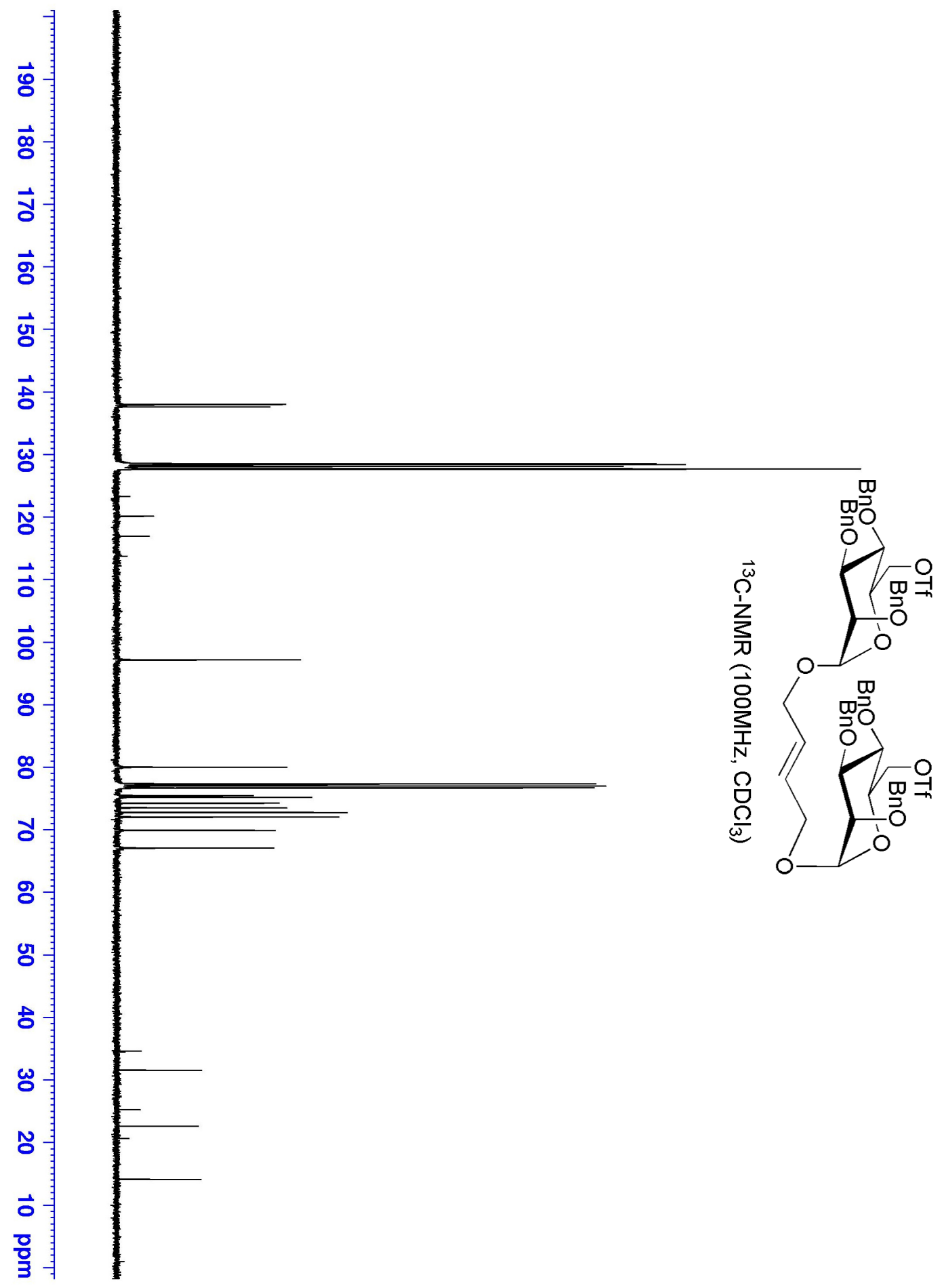




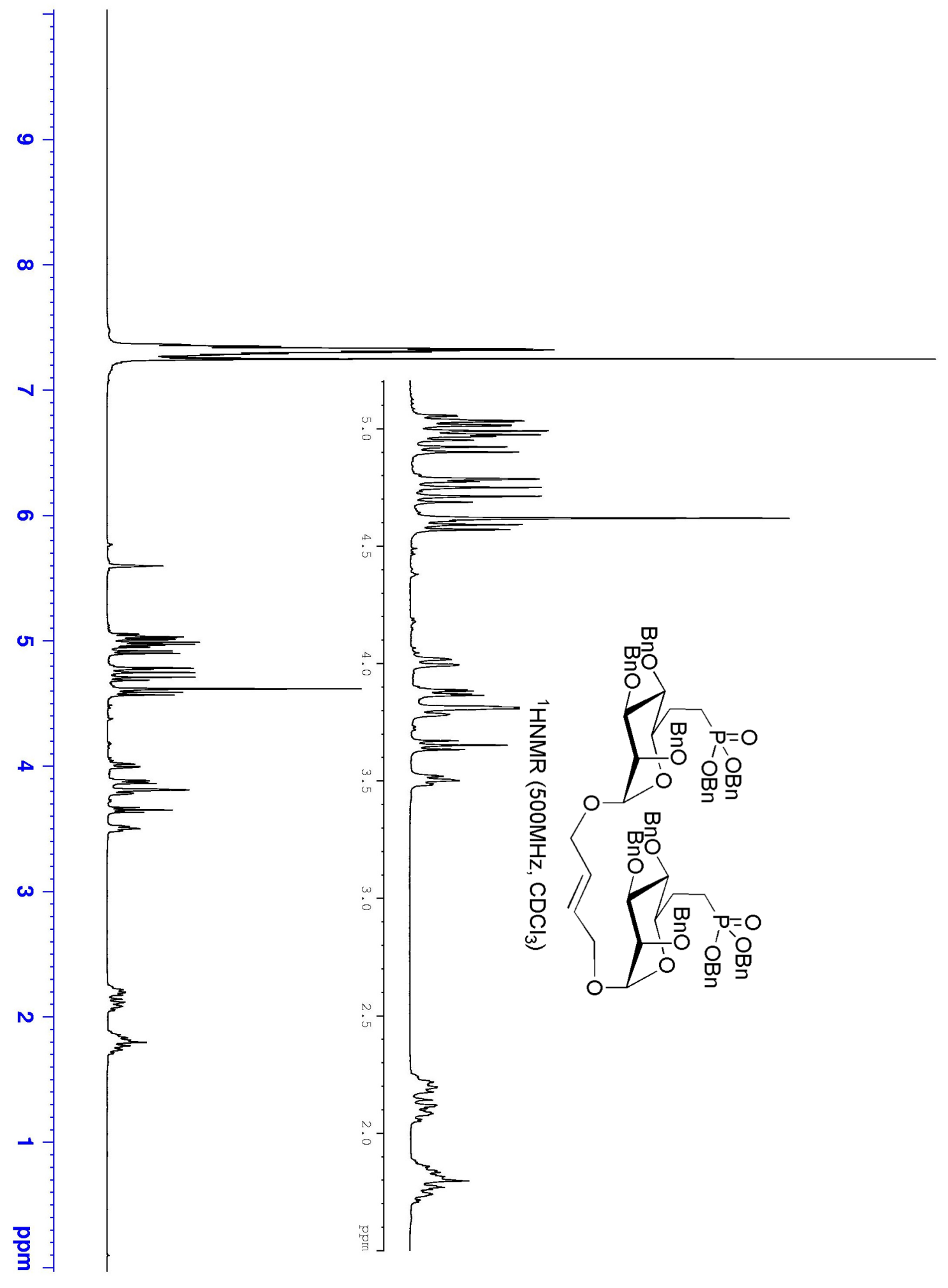




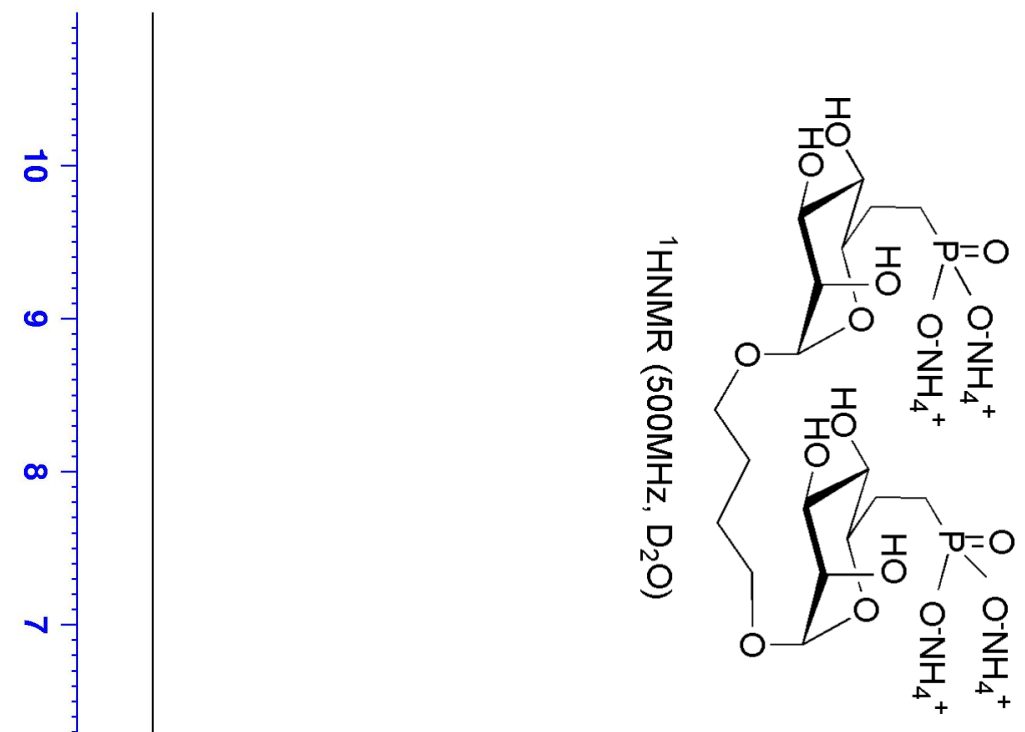

o

o
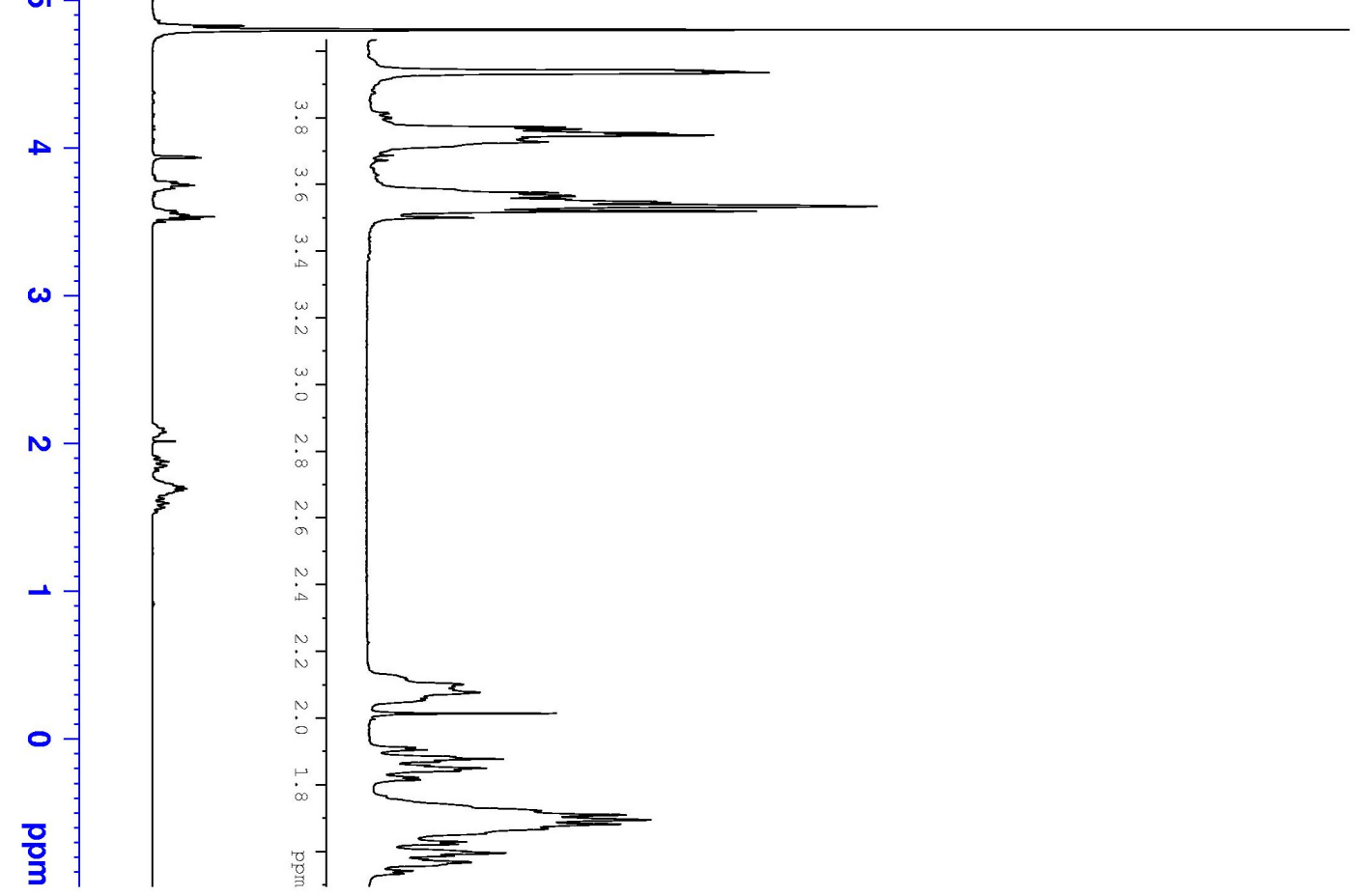


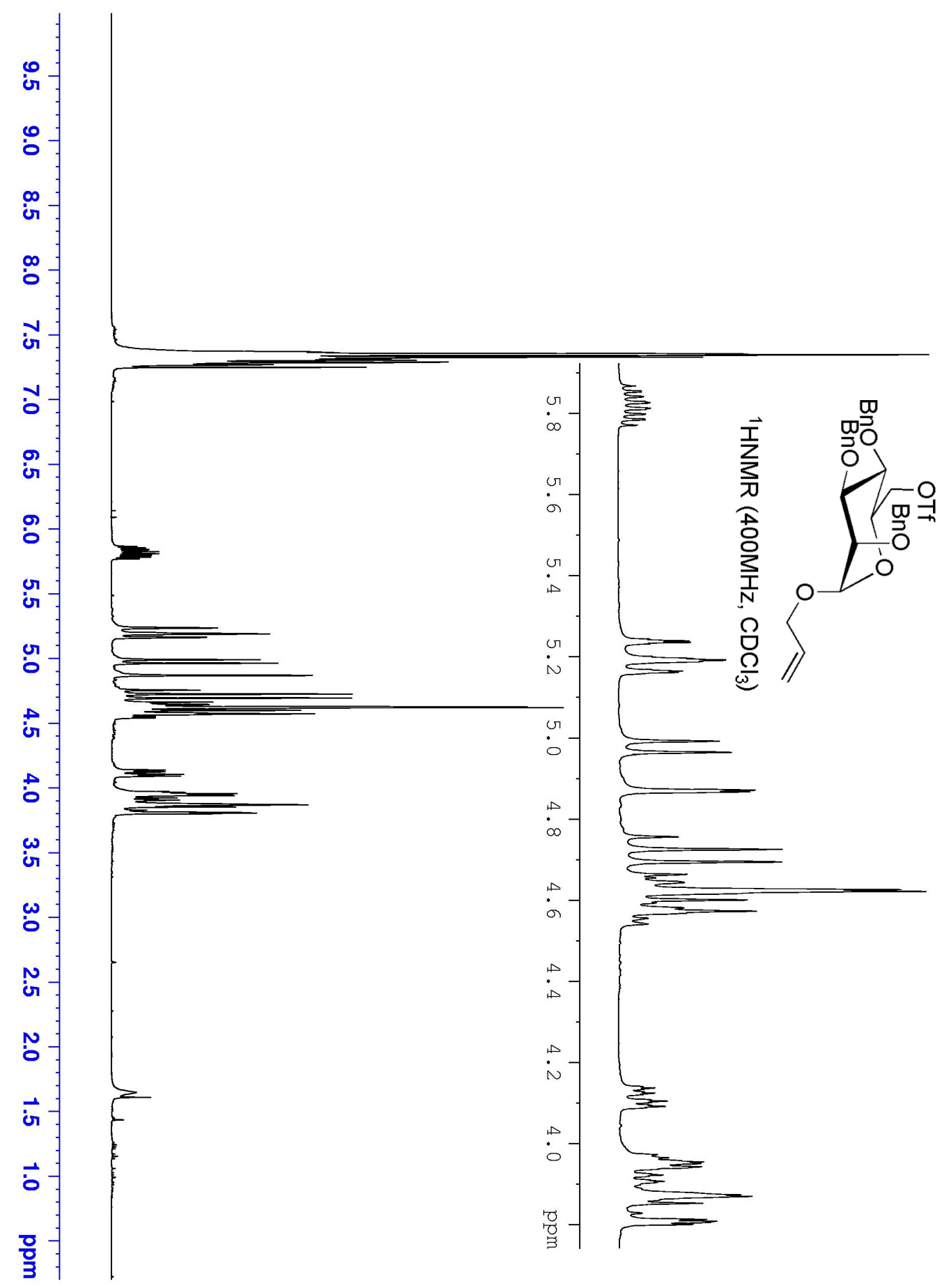




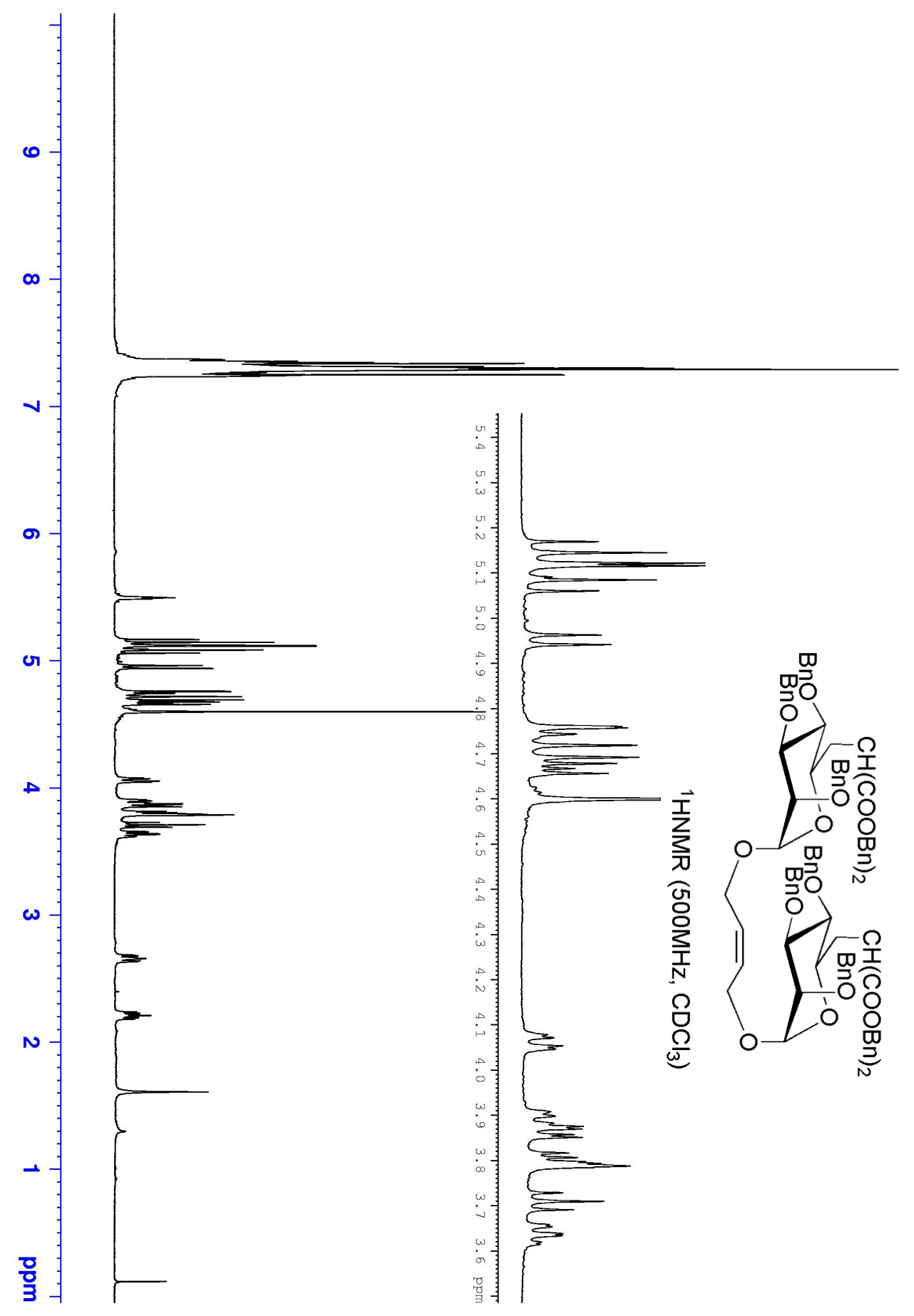




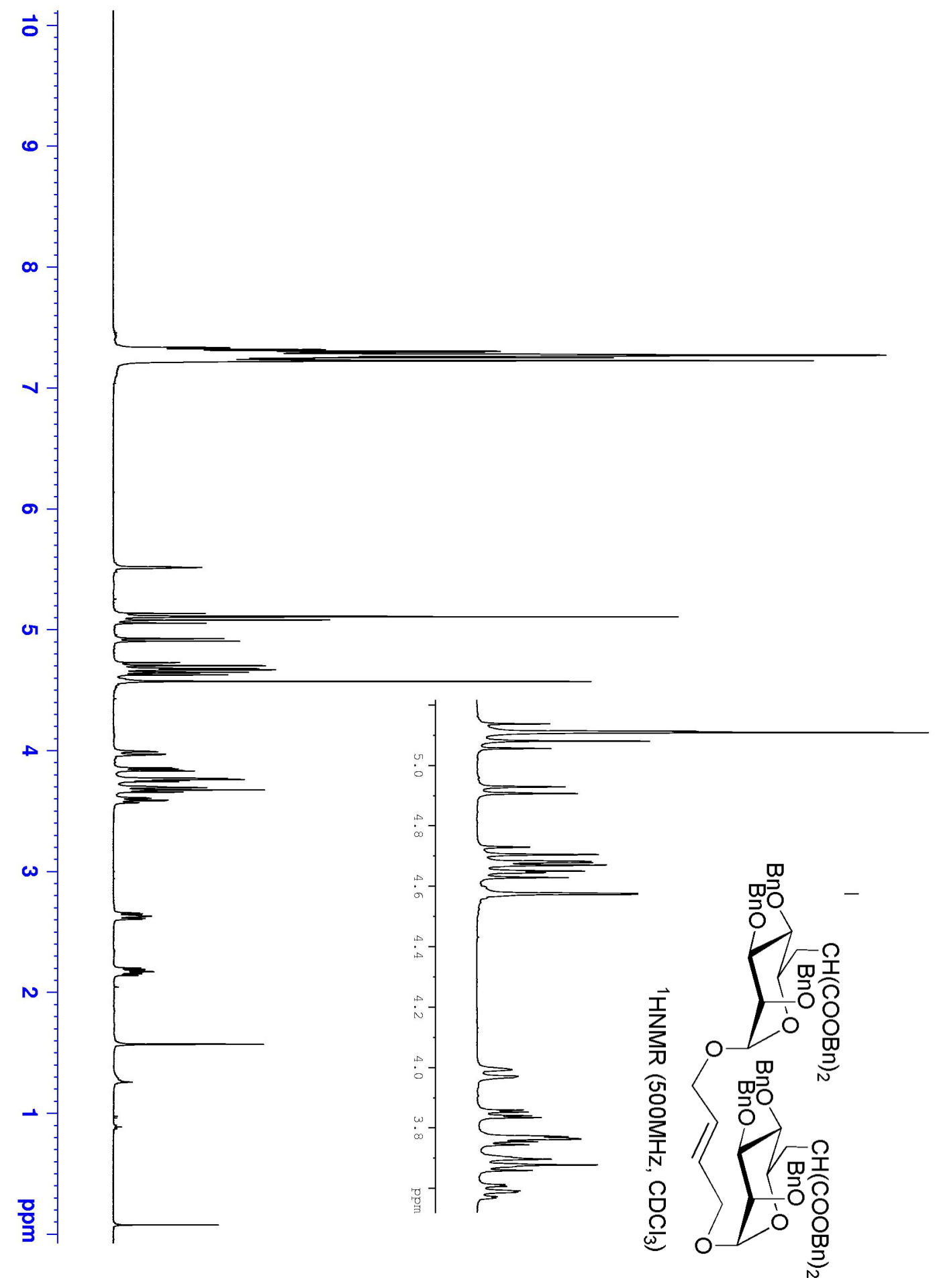




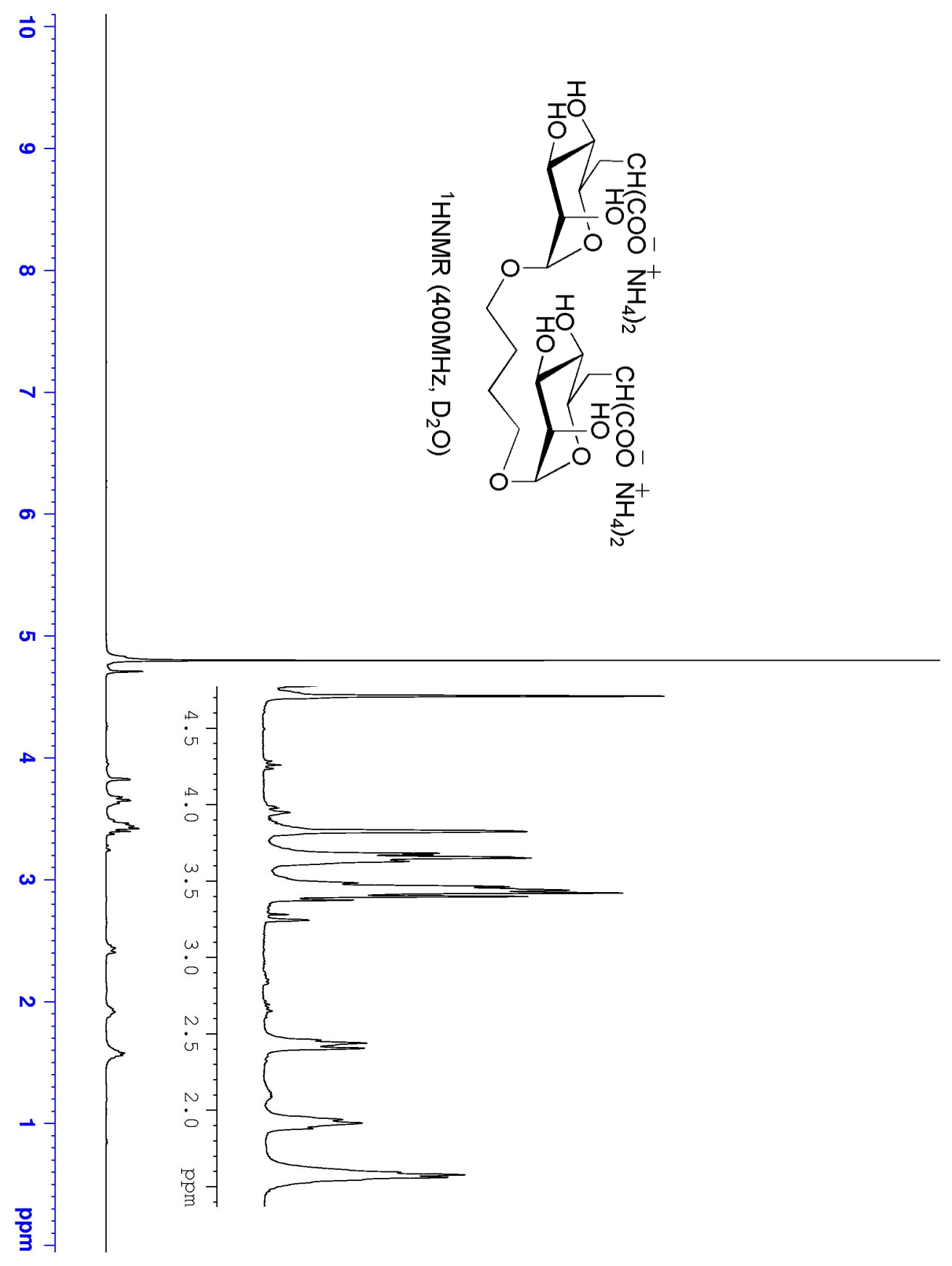




\section{Radioligand Displacement Assays}

Materials: D-Mannose 6-phosphate (M6P), disodium salt, hydrate (M-6876), $\beta$-Dglucose 6-phosphate (G6P), monosodium salt, (G-7879), and cyanogen bromide (CNBr)activated-Sepharose 4B (C-9142) were purchased from Sigma (St. Louis, MO). IODOGEN $^{\mathrm{TM}}$ pre-coated tube iodination reagent was obtained from Pierce (Rockford, IL). Carrier-free Na ${ }^{125} \mathrm{I}$, specific activity $\sim 17 \mathrm{Ci} / \mathrm{mg}$, was obtained from Perkin-Elmer (Boston, MA). Pentamannosyl phosphate (PMP) was prepared from the native Y-2448 $O$-phosphomannan of Hansenula holstii according to the method of Murray and Neville. ${ }^{1}$ This material was coupled to $\mathrm{CNBr}$-activated Sepharose 4B in order to prepare M6P/IGF2R affinity resin as described previously. ${ }^{2}$ Pentamannosyl phosphate-bovine serum albumin (PMP-BSA), a pseudoglycoprotein ligand for the M6P/IGF2R was prepared by direct coupling of PMP with BSA in the presence of $\mathrm{NaCNBH}_{3}$ as described previously. ${ }^{2}$ Human $\beta$-glucuronidase (hGUS) purified from Chinese hamster ovary cells transfected with hGUS cDNA was a gift from Dr. William S. Sly, St. Louis University School of Medicine. PMP-BSA and hGUS were radioiodinated to specific activities of $50-74 \mathrm{Ci} / \mathrm{g}$ and $62-78 \mathrm{Ci} / \mathrm{g}$, respectively, using IODOGEN ${ }^{\mathrm{TM}}$ according to the manufacturer's recommendations.

Preparation of M6P/IGF2R-Sepharose resin: Soluble bovine M6P/IGF2R was purified from fetal bovine serum by the procedure of Valenzano et al. ${ }^{3}$ as modified by Byrd et al. ${ }^{4}$ In brief, $500 \mathrm{~mL}$ of serum was diluted with an equal volume of buffer to yield final concentrations of $25 \mathrm{mM}$ HEPES, pH 7.4, $0.15 \mathrm{M} \mathrm{NaCl}$, 0.1\% Triton X-100, 5 $\mathrm{mM} \beta$-glycerophosphate (column buffer conditions). This diluted serum was pumped at a rate of $1 \mathrm{~mL}$ per min over a $5-\mathrm{mL}$ column of PMP-Sepharose. The column was subsequently washed with $5 \times 5 \mathrm{~mL}$ of column buffer and then eluted with $5 \times 5 \mathrm{~mL}$ of column buffer supplemented with $10 \mathrm{mM}$ M6P. The fractions containing purified receptor were identified by sodium dodecyl sulfate-polyacrylamide gel electrophoresis with Coomassie blue R-250 staining and pooled. The pooled material was dialyzed to remove M6P, lyophilized and stored at $-80{ }^{\circ} \mathrm{C}$. Analysis of material purified by these methods, using gel filtration chromatography and native gel electrophoresis, indicated 
that the receptor is present as both a monomer $(\sim 70 \%)$ and a dimer $(30 \%) .{ }^{4}$ M6P/IGF2RSepharose resin for use in ligand binding assays was prepared by coupling the purified, redissolved receptor to cyanogen bromide-activated Sepharose $4 \mathrm{~B}$ according to the manufacturer's instructions. For this purpose, $1 \mathrm{~g}$ of $\mathrm{CNBr}$-activated Sepharose 4B dry resin was rehydrated in $15 \mathrm{~mL}$ of $1 \mathrm{mM} \mathrm{HCl}$ for $15 \mathrm{~min}$ at room temperature then washed with 4 x $10 \mathrm{~mL}$ of $1 \mathrm{mM} \mathrm{HCl}$ followed by 2 x $10 \mathrm{~mL}$ of coupling buffer $(0.1 \mathrm{M}$ $\left.\mathrm{NaHCO}_{3}, \mathrm{pH} 8.0,0.5 \mathrm{M} \mathrm{NaCl}\right)$. The wet resin cake ( 3 $\mathrm{mL}$ volume) was transferred to a tube containing 1.2-1.4 mg of purified receptor dissolved in $5 \mathrm{~mL}$ of coupling buffer. The mixture was incubated end-over-end at $4{ }^{\circ} \mathrm{C}$ for 16 hours for coupling. Uncoupled sites on the resin were blocked by final incubation at $4{ }^{\circ} \mathrm{C}$ with $0.5 \mathrm{M}$ glycine, $\mathrm{pH} 8.0$, to produce a final affinity reagent of $\sim 0.5 \mathrm{mg} \mathrm{M} 6 \mathrm{P} / \mathrm{IGF} 2 \mathrm{R}$ per $\mathrm{mL}$ resin beads. This material was stored as a $50 \%$ slurry at $4{ }^{\circ} \mathrm{C}$ in $25 \mathrm{mM}$ HEPES, pH 7.4, $0.15 \mathrm{M} \mathrm{NaCl}, 0.02$ $\mathrm{mM} \mathrm{NaN}, 0.05 \%$ Triton X-100 until use.

Competitive Binding Analysis for M6P Analogues: A M6P/IGF2R-Sepharose 4B resin-based radioligand displacement assay was used to evaluate the ability of each of the M6P analogues to bind the receptor. When ${ }^{125}$ I-PMP-BSA was used as the radioligand, aliquots $(10 \mu \mathrm{L})$ of receptor resin were incubated with $5 \times 10^{5} \mathrm{cpm}$ of ${ }^{125}$ I-PMP-BSA in the presence of increasing concentrations of the M6P analogues $(0 \mathrm{mM}$, or 0.0001 to 10 $\mathrm{mM}$ ) in assay buffer (25 mM HEPES, pH 7.4, 0.15 M NaCl, 0.05\% Triton X-100) for 16 $\mathrm{h}$ at $10{ }^{\circ} \mathrm{C}$ on an end-over-end clinical mixer. As positive and negative controls, parallel assays were done that contained, respectively, increasing concentrations of M6P $(0.0001$ to $10 \mathrm{mM})$ or $\mathrm{G} 6 \mathrm{P}(1,3$ and $10 \mathrm{mM})$. The resin pellets were collected by centrifugation for $30 \mathrm{sec}$ at $8,000 \mathrm{x} \mathrm{g}$ at $4{ }^{\circ} \mathrm{C}$ and the resin pellets were washed with $2 \times 1 \mathrm{~mL}$ of icecold assay buffer. The tips of the tubes bearing the resin pellets were cut and counted in a $\gamma$ counter. The assay was done in the same way when ${ }^{125}$ I-hGUS was used as the radioligand, except that $2.5 \times 10^{5} \mathrm{cpm}$ of ${ }^{125} \mathrm{I}$-hGUS was substituted for the PMP-BSA. The data were converted into percentage binding values based on comparison with the analogue-free controls (designated as $100 \%$ binding). The competitive binding data were graphed as semi-log plots of binding vs. concentration of M6P, G6P or the analogues. Best-fit curves were generated by nonlinear regression analysis using Prism GraphPad software (San Diego, CA), which also allowed estimation of $\mathrm{IC}_{50}$, the concentration that 
displaces $50 \%$ of radioligand binding. Values for relative binding affinity (RBA) for the $\mathrm{M} 6 \mathrm{P}$ analogues were calculated by dividing the $\mathrm{IC}_{50}$ value for each analogue into that of M6P for a given experiment.

\section{References:}

1. Murray, G. J.; Neville, D. M., Jr.: J. Biol. Chem. 1980, 255, 11942-11948.

2. Byrd, J. C.; Devi, G. R.; De Souza, A. T.; Jirtle, R. L.; MacDonald, R. G. J. Biol. Chem. 1999, 274, 24408-24416.

3. Valenzano, K. J.; Kallay, L. M.; Lobel, P. Anal. Biochem. 1993, 209, 156-162.

4. Byrd, J. C.; Park, J. H. Y.; Schaffer, B. S.; Garmroudi, F.; MacDonald, R. G. J. Biol. Chem. 2000, 275, 18647-18656. 


\section{Displacement Curves}
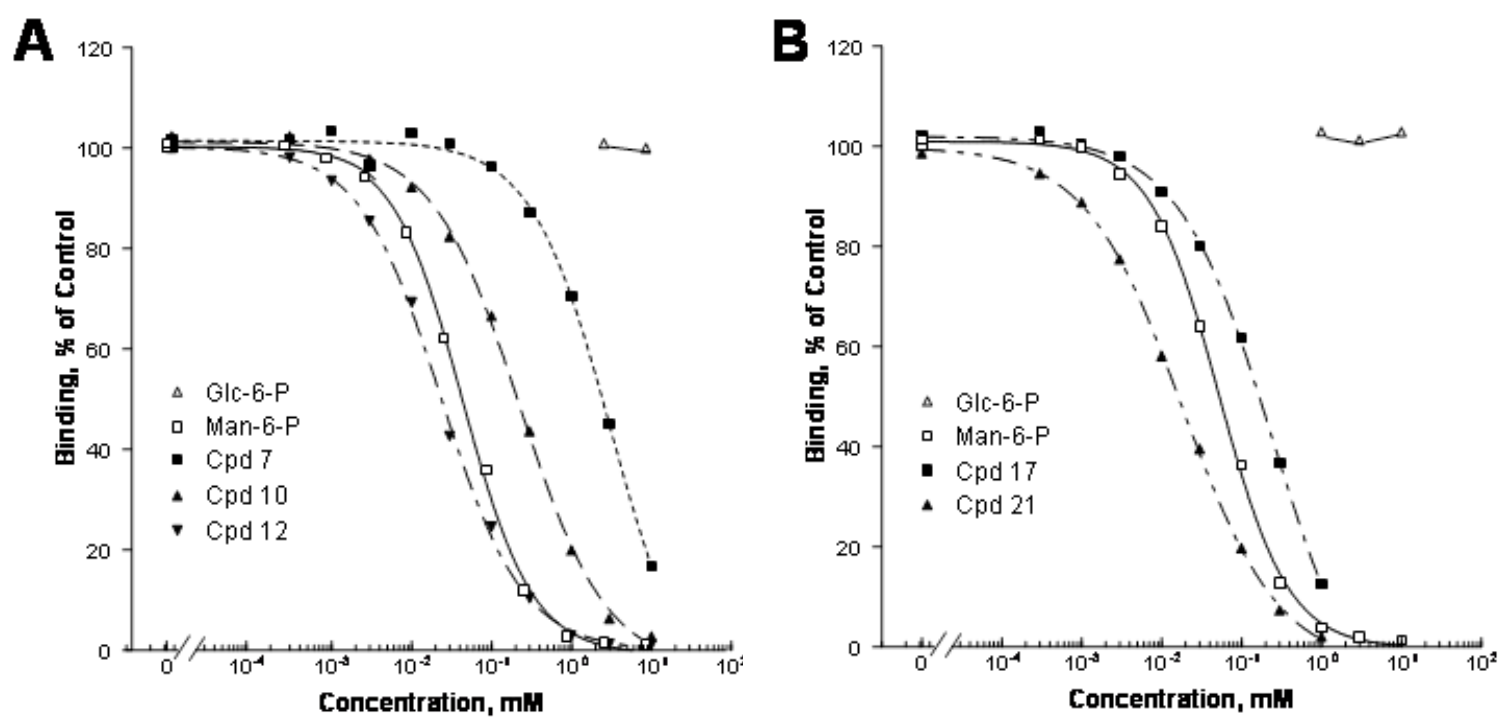

Figure S1. Competitive binding analysis for M6P surrogates in displacement of PMPBSA from M6P/IGF2R-Sepharose. Each of the compounds was tested at the indicated concentrations as described in Materials and Methods for its ability to displace ${ }^{125}$ I-PMPBSA tracer from the M6P/IGF2R-Sepharose resin. M6P and G6P were analyzed in parallel as positive and negative controls, respectively. Panel A. Monovalent compounds 7, 10 and 12; Panel B. Bivalent compounds 17 and 21. Curves were fitted for each data set by nonlinear regression. These data are representative of 4-6 replicate experiments. 

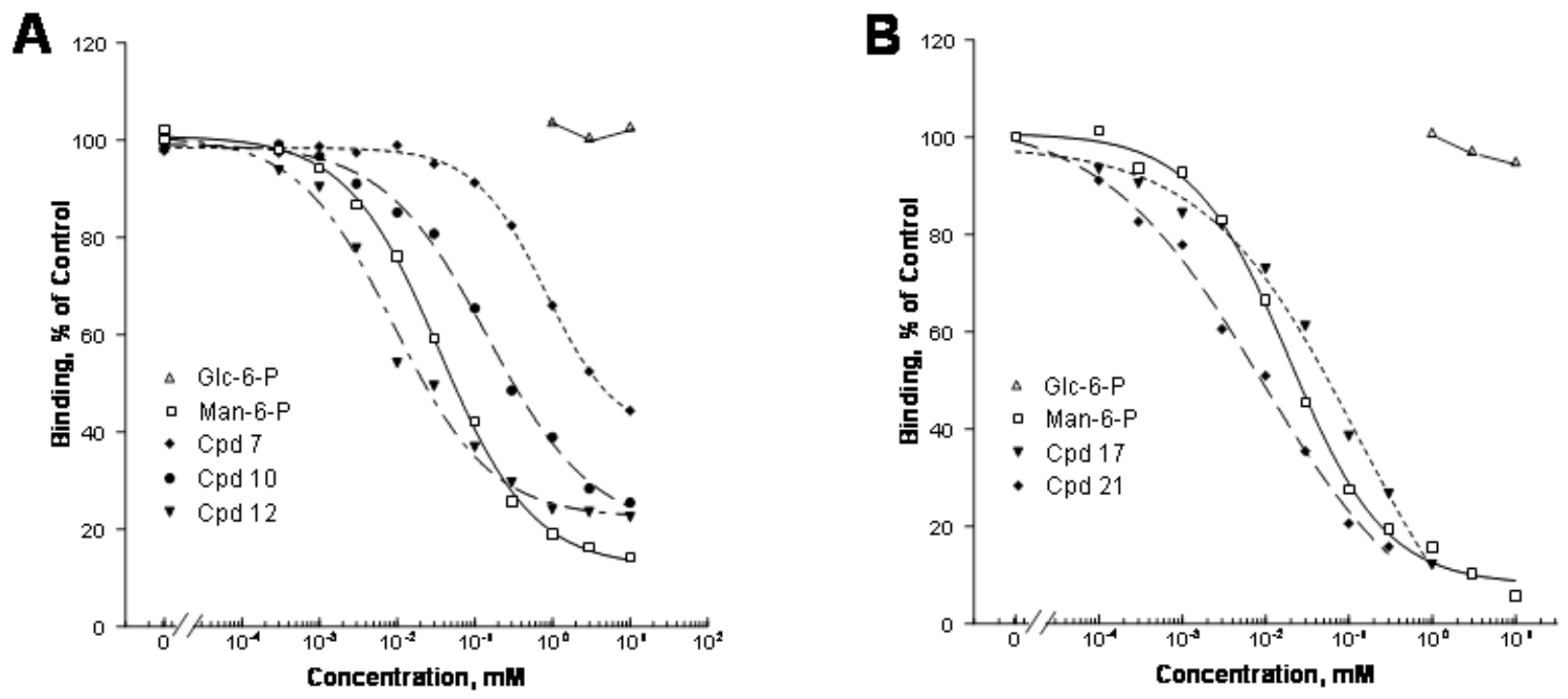

Figure S2. Competitive binding analysis for M6P surrogates in displacement of hGUS from M6P/IGF2R-Sepharose. Each of the compounds was tested at the indicated concentrations as described in Materials and Methods for its ability to displace ${ }^{125} \mathrm{I}$ hGUS tracer from the M6P/IGF2R-Sepharose resin. M6P and G6P were analyzed in parallel as positive and negative controls, respectively. Panel A. Monovalent compounds 7, 10 and 12; Panel B. bivalent compounds 17 and 21. Curves were fitted for each data set by nonlinear regression. These data are representative of 4-6 replicate experiments. 


\section{Receptor/Ligand Molecular Dynamics \& Docking}

Atomic Coordinates: The crystal structure of mannose 6-phosphate bound to the Nterminal domains 1-3 of the cation independent mannose 6-phosphate receptor ${ }^{1}$ was obtained from the Brookhaven Protein Data Bank (http://www.rcsb.org/pdb) (entry code: 1SZ0). Chain A (“1SZ0A") or Chain B (“1SZ0B”) and all non-protein records were removed from the coordinate file using Autodock Tools. Chain A was further processed to sample additional conformational space to which domains 1-3 may have access.

Molecular Dynamics: To sample additional conformational space, beyond the fixed coordinates in the crystal lattice, two molecular dynamics (MD) simulations were performed on chain A from structure 1SZ0, using GROMACS 3.2.2 The first simulation used chain A with bound mannose 6-phosphate (resid M6P500). M6P was processed using PRODRG ${ }^{3}$ to obtain the necessary topology for GROMACS input. Next, the chain A-M6P complex was minimized using a 200 step energy minimization to remove bad contacts (convergence reached at step 191). After placing the complex in a virtual box solvated with water (-d 0.75), a 20 picosecond position-restrained dynamics simulation was performed to soak the complex. After soaking, a 500 picosecond unrestrained MD simulation was performed to equilibriate the complex. For the second MD simulation, M6P was replaced by a terminally 6-phosphorylated $\alpha$-1,2-linked mannobiose. The $\alpha$ anomer was employed. This disaccharide was chosen to emulate binding of the natural ligand, $\beta$-glucuronidase (hGUS). Initial coordinates of the disaccharide were obtained using AutoDock $3.0^{4}$ to dock the disaccharide to chain A. The MD simulation performed on the docked disaccharide-chain A complex was performed in a manner identical to that of docked M6P. The receptor coordinates resulting from each MD simulation were then taken as additional, potentially relevant receptor conformations with which to perform automated docking experiments.

Ligand Preparation: Ligands were drawn using the Chem3D 8.0 and ChemDraw 8.0 software packages (CambridgeSoft). Assignment of partial charges, rotable bonds, active 
torsions, and energy minimization was performed with PRODRG. ${ }^{3}$ All ligands were prepared with phosphate and malonate moieties fully deprotonated.

Docking: Virtual docking experiments were performed using Autodock 3.0.5. ${ }^{4}$ Each trial was run in a grid map with X x Y x Z dimensions $=25 \times 24 \times 17 \AA$ centered at C-5 of M6P from the reference structure. Grid spacing was set at $0.225 \AA$. The Lamarckian Genetic Algorithm was used as the search method. Trials on chains A and B consisted of 100 runs each, with a maximum of 2,500,000 energy evaluations. Trials on conformations obtained from MD simulations consisted of 40 runs each, with a maximum of 2,500,000 energy evaluations. Lowest $\Delta \mathrm{G}_{\text {binding }}$ was recorded for each docking trial.

Computer hardware: Docking experiments were run on a cluster of five $2.2 \mathrm{GHz}$ Athlon machines running Redhat Linux 9.0. Images were generated using VMD. 5

\section{Table S1}

\begin{tabular}{|l|l|l|l|l|}
\hline \multicolumn{5}{|c|}{$\begin{array}{l}\text { Lowest Predicted } \Delta \text { G binding (Autodock 3.05) } \\
(\mathrm{kcal} / \mathrm{mol})\end{array}$} \\
\hline & 1SZ0A & 1SZ0B & 1SZ0A & 1SZ0A \\
\hline Cpd. & & & M6P 500 ps & disacch. 500 ps \\
& & & & \\
\hline M6P & -7.02 & -8.01 & -7.69 & -7.14 \\
\hline G6P & -6.83 & -7.40 & -7.89 & -6.51 \\
\hline $\mathbf{7}$ & -6.74 & -7.57 & -7.05 & -6.74 \\
\hline $\mathbf{1 0}$ & -6.82 & -7.75 & -7.03 & -6.48 \\
\hline $\mathbf{1 2}$ & -7.13 & -7.59 & -8.35 & -7.18 \\
\hline
\end{tabular}




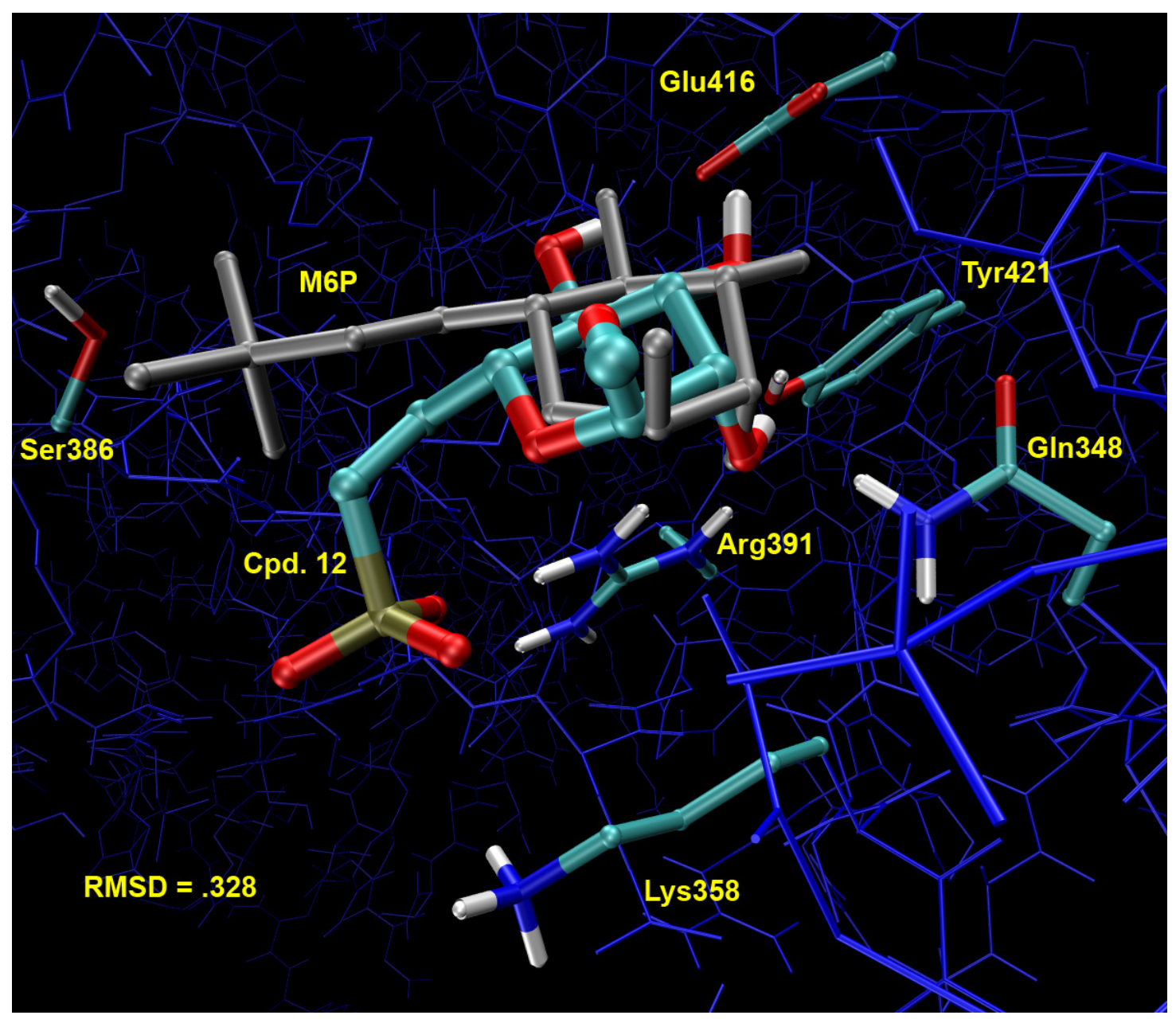

Figures S3 Autodocked ligand 12 overlaid on crystal structure 1SZ0 chain A with bound M6P (silver). A comparison of the conformations of the two bound ligands yields an RMSD of $0.328 \AA$. As can be seen, the ring atoms overlay especially well. Comparison of only the C-1 to C-5 (i.e. ring) atoms for both ligands, inclusive of their attached oxygens, yields a RMSD of $0.168 \AA$. 


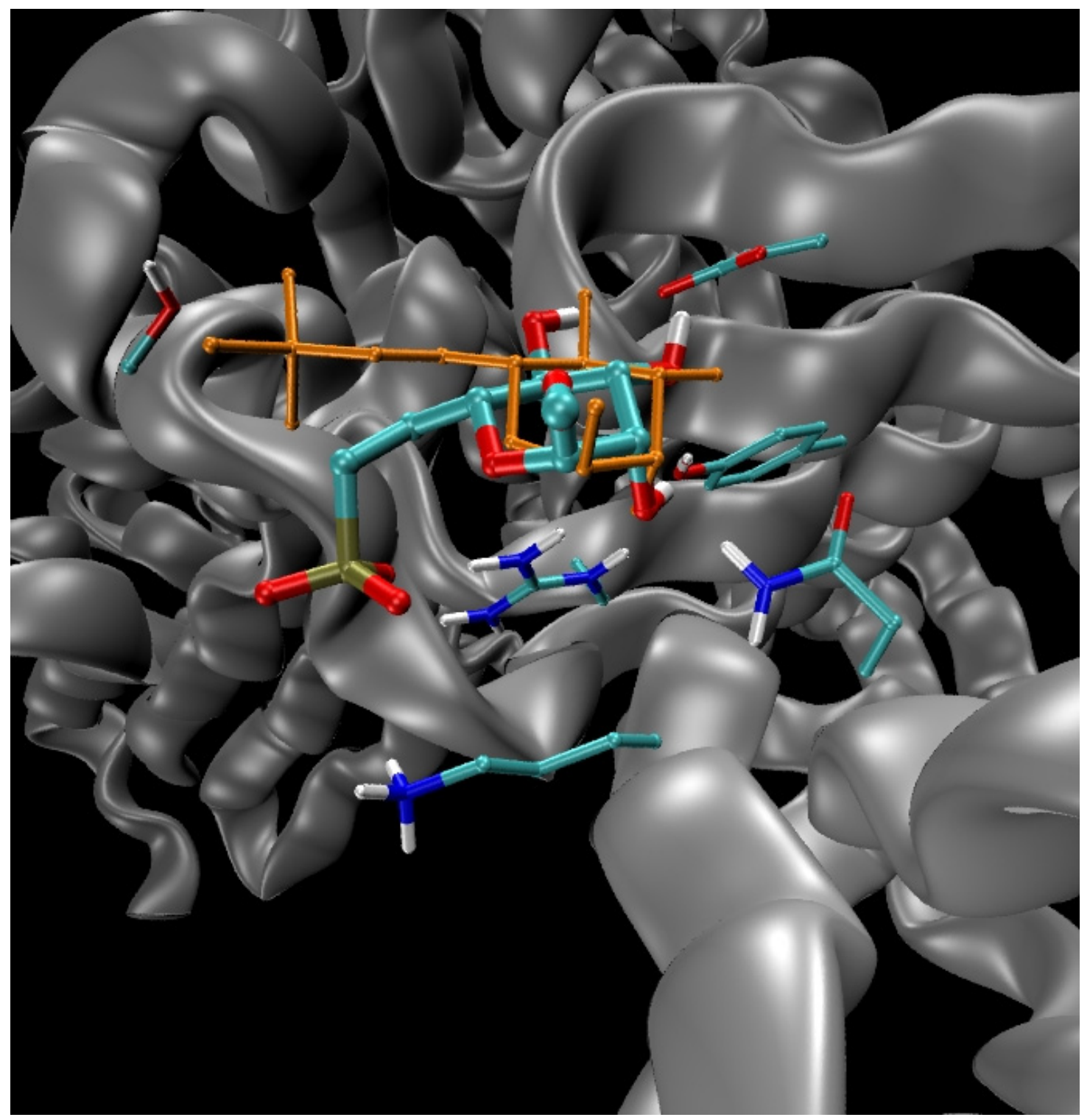

Figure S4 Ribbon diagram of the carbohydrate binding domain of the CI-MPR domain 1-3 construct. Autodocked ligand $\mathbf{1 2}$ is overlaid on crystal structure 1 SZ0 chain A with bound M6P (orange), as in Figure S3.

\section{References:}

1. Kim, J.-J. P.; Olson, L. J.; Dahms, N. M. J. Biol. Chem. 2004, 279, 34000-34009.

2. Berendsen, H. J. C.; van der Spoel, D.; van Drunen, R. Comp. Phys. Comm. 1995, 91, 43-56.

3. Schuettelkopf, A. W.; van Aalten, D. M. F. Acta Crystallographica 2004, D60, 1355-1363.

4. Morris, G. M.; Goodsell, D. S.; Halliday, R.S.; Huey, R.; Hart, W. E.; Belew, R. K.; Olson, A. J. J. Comp. Chem. 1998, 19, 1639-1662.

5. Humphrey, W.; Dalke, A.; Schulten, K. J. Molec. Graphics 1996, 14, 33-38. 